\title{
Performance of a reversible heat pump/organic Rankine cycle unit coupled with a passive house to get a positive energy building
}

Olivier Dumont, Carolina Carmo, Valentin Fontaine, François Randaxhe, Sylvain Quoilin, Vincent Lemort, Brian Elmegaard \& Mads P. Nielsen

To cite this article: Olivier Dumont, Carolina Carmo, Valentin Fontaine, François Randaxhe, Sylvain Quoilin, Vincent Lemort, Brian Elmegaard \& Mads P. Nielsen (2016): Performance of a reversible heat pump/organic Rankine cycle unit coupled with a passive house to get a positive energy building, Journal of Building Performance Simulation

To link to this article: http://dx.doi.org/10.1080/19401493.2016.1265010

Published online: 15 Dec 2016.

Submit your article to this journal $\pi$

Q View related articles 5

View Crossmark data $₫$ 


\title{
Performance of a reversible heat pump/organic Rankine cycle unit coupled with a passive house to get a positive energy building
}

\author{
Olivier Dumont ${ }^{\mathrm{a} *}$, Carolina Carmo $^{\mathrm{b}}$, Valentin Fontaine ${ }^{\mathrm{a}}$, François Randaxhe ${ }^{\mathrm{a}}$, Sylvain Quoilin ${ }^{\mathrm{a}}$, Vincent Lemort ${ }^{\mathrm{a}}$, \\ Brian Elmegaard ${ }^{\mathrm{c}}$ and Mads P. Nielsen ${ }^{\mathrm{b}}$
}

${ }^{a}$ Thermodynamics and Energetics Laboratory, Chemin des chevreuils, 7 B49, 4000 Liege, Belgium; ${ }^{b}$ Department of Energy Technology, Aalborg University, Aalborg, Denmark; ' ${ }^{c}$ Department of Mechanical Engineering, DTU, Lungby, Denmark

(Received 29 December 2015; accepted 22 November 2016)

\begin{abstract}
This paper presents an innovative technology that can be used to deliver more renewable electricity production than the total electrical consumption of a building while covering the heat demand on a yearly basis. The technology concept uses a heat pump (HP), slightly modified to revert its cycle and generate electricity, coupled to a solar thermal collector roof. This reversible HP/organic Rankine cycle unit presents three operating modes: direct heating, HP and organic Rankine cycle. This work focuses on describing the dynamic model of the multi-component system followed by a techno-economic analysis of the system under different operational conditions. Sensitivity studies include: building envelope, climate, appliances, lighting and heat demand profiles. It is concluded that the HP/ORC unit can turn a single-family house into a PEB under certain weather conditions (electrical production of $3012 \mathrm{kWh} /$ year and total electrical consumption of $2318 \mathrm{kWh} / \mathrm{year}$ ) with a $138.8 \mathrm{~m}^{2}$ solar roof in Denmark.
\end{abstract}

Keywords: heat pump; organic Rankine cycle; positive energy building; dynamic simulation; annual performance

\section{Introduction}

\subsection{Context}

By 2020, greenhouse gases emissions must be reduced by $20 \%$ as compared to the levels of 1990 , according to European objectives (20-20-20 objectives) (European Commission 2012). This goal should be achieved through an increase in the proportion of renewable energy sources from $9 \%$ to $20 \%$ together with a $20 \%$ increase in system energy efficiency. Households account for $27 \%$ of the final energy consumption (European Commission 2012) and therefore can constitute an important part of the solution. Various technologies and concepts are being investigated, developed and implemented in the building sector. Net Zero Energy Buildings (Marszal et al. 2011) are expected to gain a significant importance: by 2019, all new buildings in the European Union should present a renewable energy production higher than their primary energy consumption (European Commission 2013).

Net Zero Energy Buildings and, by extension, positive energy buildings (PEBs) will therefore play a major role in the future. PEBs offer different advantages: relatively high independence from energy prices, lower long-term running costs and zero fossil-fuel consumption among others. Amongst the different available energy sources, solar energy is pointed as a very interesting choice for
PEB because it is free, $100 \%$ renewable and available in abundance.

\subsection{Concept - the reversible heat pump/organic Rankine cycle unit}

In this paper, the concept of coupling a reversible heat pump (HP)/organic Rankine cycle (ORC) unit to a passive house to get a PEB is investigated (Figure 1). A HP/ORC reversible unit is a HP which is slightly modified to be able to work as an ORC. This reversible unit coupled to a large solar thermal roof and a horizontal ground heat exchanger constitutes a combined system able to provide electricity and heat to the household with passive house characteristics. The system can operate in three modes: the direct heating $(\mathrm{DH})$ mode uses the heat collected from the roof to supply the thermal energy in a water store which supplies the floor heating $(\mathrm{FH})$ and domestic hot water (DHW). In case of unfavourable meteorological conditions, the HP mode allows to heat the thermal energy store efficiently. On the other hand, in case of solar energy availability, the latter is collected and used to cover the heat demand. Finally, a large quantity of heat is generated on the roof during mid-season and summer periods. This surplus heat can be converted into electricity by means of the ORC (Dumont, Quoilin, and Lemort 2015).

\footnotetext{
*Corresponding author. Email: Olivier.dumont@ulg.ac.be
} 


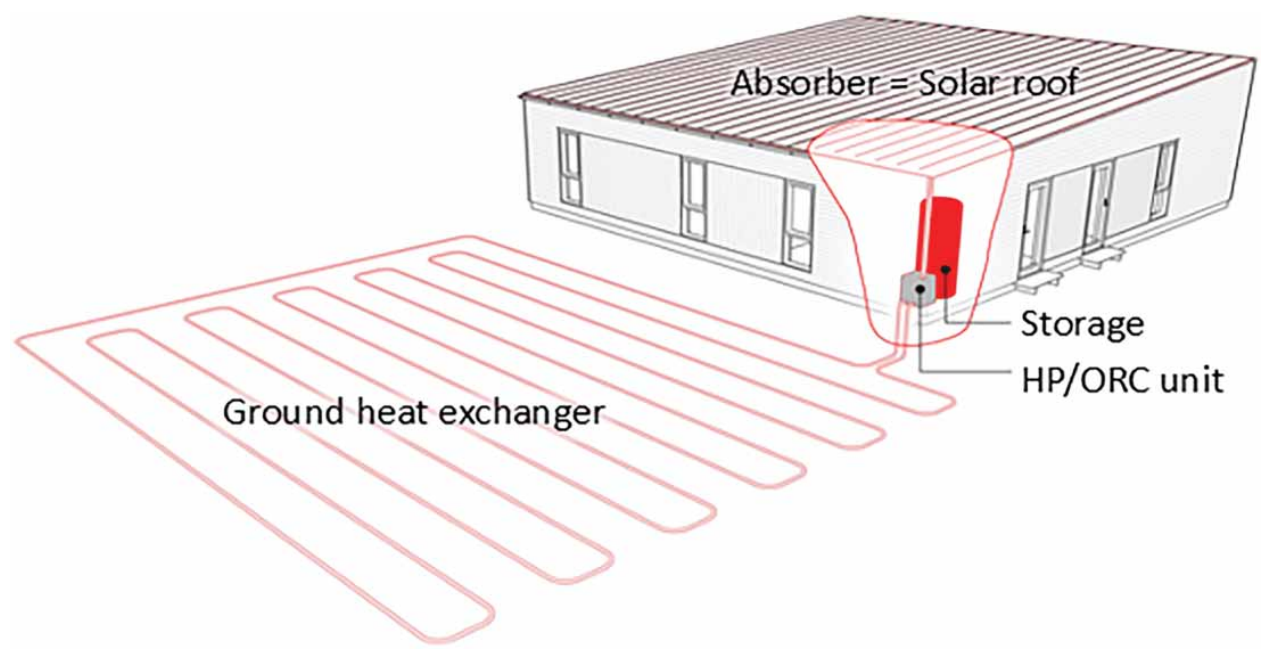

Figure 1. The reversible HP/ORC unit integrated in the house (Dumont, Quoilin, and Lemort 2015).

The first investigation on such a system has been introduced in 2011 (Schimpf, Uitz, and Span 2011). A thermoeconomical tool was developed but only a small area of collector $\left(12 \mathrm{~m}^{2}\right)$ and a vertical ground heat exchanger was considered. In 2013, the modelling and sizing of such a unit has been investigated. The optimal sizing based on an existing house in Denmark (300 m long horizontal ground heat exchanger, 5001 heat storage and $138.8 \mathrm{~m}^{2}$ solar roof) lead to a $5 \mathrm{kWe}$ ORC system (Quoilin, Dumont, and Lemort 2013, 2015). A large solar roof is considered based on the existing house in Denmark. The main disadvantage of a large solar roof is the low solar fraction in summer. However, in this study case, this problem is avoided thanks to the electricity production through the ORC system with the surplus heat collected in the roof.

The theoretical results were promising with an ORC electrical production seven times higher than the electrical HP annual consumption. A prototype has therefore been built and successfully tested (Dumont, Quoilin, and Lemort 2014,2015 ). A cycle efficiency of $4.2 \%$ was achieved in ORC mode (with condensation and evaporation temperature, respectively of $25^{\circ} \mathrm{C}$ and $88^{\circ} \mathrm{C}$ ) and a COP of 3.1 was obtained in HP mode (with condensation and evaporation temperature, respectively of $61^{\circ} \mathrm{C}$ and $21^{\circ} \mathrm{C}$ ).

\subsection{Scope}

The first part of this paper details the models of: the reversible $\mathrm{HP} / \mathrm{ORC}$ unit, the passive house, the horizontal ground heat exchanger and the flat plate solar roof collector. Each sub-model, the global model and the control strategy of the system are described in detail in Section 2.

The model is then used to simulate and assess the energy system performance in typical days along the year for this innovative concept (Section 3). Followed by a study of influence including building envelope, location, heat demand, lighting and appliances profiles is performed based on annual results (Section 4)

Finally, an economic comparison with a HP and photovoltaic panels (PV) is made.

\section{Modelling methodology}

\subsection{Simulation tool}

Among simulation programs, some are dedicated to building performance simulation (IDA ICE, ESP-r, EnergyPlus, TRNSYS, WUFI ${ }^{\circledR}$ Plus, etc.) while others are more general (Dymola/Modelica, MATLAB/ Simulink, IDA SE, etc.). Simulation tools like Matlab-Simulink need the model to be implemented, in a state-space form in which causal relations play an important role. A simulation language based on an object-oriented approach and physically oriented connections - Modelica - is chosen as simulation tool to model the new system proposed in this work. Recently, Modelica has become more and more used in building performance simulation. The Lawrence Berkeley National Laboratory developed a Modelica library called Buildings, that contains a large number of HVAC components and a multi-zone building model (Wetter, Zuo, and Nouidui 2011). Also, the RWTH Aachen and UdK Berlin (NytschGeusen and Unger 2009) are developing Modelica libraries for HVAC-systems and building models. Besides, many models for HVAC components and different thermal zone models, the RWTH Aachen library offers a database of manufacturer's data for building technology (Muller and Badakhshani 2010).

Before describing each sub-model and the control strategy, it is important to note that the dynamic modelling of a system including several sub-systems does not systematically require each model to be dynamic: components characterized by relatively low time constants can be modelled 
as quasi-steady-state, since their fast dynamics are not relevant to the overall simulation and can substantially impact the computational effort. In this case, it was shown previously (Perers 1997; Schnieders 1997; Chow 2003; Fischer et al. 2004; Dumont, Quoilin, and Lemort 2014; Freeman, Hellgardt, and Markides 2015) that the dynamics of the reversible unit can be neglected because of its small inertia compared to other sub-systems.

\subsection{Reversible HP/ORC unit}

An experimental investigation has been carried out on the unit in HP and ORC mode over a wide range of conditions (Dumont, Quoilin, and Lemort 2015). Based on the measurements, semi-empirical models have been calibrated for each component (heat exchangers, compressor, pump and pipes). These models are then combined to simulate the behaviour of the global system. Finally, polynomial regressions, fitted on the global validated model, allow to evaluate the outputs of the reversible unit. These are presented by the authors in a former paper (Dumont, Quoilin, and Lemort 2014). The T-s diagrams for the HP and the ORC are given in the appendix (Figures A1 and A2). A cycle efficiency of $5.3 \%$ is achieved in ORC mode (with condensation and evaporation temperature, respectively of $25^{\circ} \mathrm{C}$ and $88^{\circ} \mathrm{C}$ ) and a COP of 4.21 is obtained in HP mode (with condensation and evaporation temperature, respectively of $61^{\circ} \mathrm{C}$ and $21^{\circ} \mathrm{C}$ ).

\subsection{Storage}

The basic type of hot water storage tank in the HP/ORC system is shown in Figure A3. It is a typical DHW tank system installed in single-family houses in Denmark (5001). The water tank consists of a stainless steel cylinder with two built-in spiral heat exchangers (HXs) - one going from mid-height to bottom of the tank and another going from bottom to the top of the tank. The working fluid in the HP/ORC unit is circulated through the mid-height helical heat exchanger, while the cold water from the grid is circulated through the all-through heat exchanger to supply DHW. In the current work, this stratified sensible thermal storage is modelled by a one-dimensional finitevolume method comprising 20 isothermal segments with equal volume (Carmo et al. 2015). The model accounts for heat losses to the environment, internal heat conduction between adjacent cells as well as for internal natural convection whenever an internal reversed temperature gradient occurs. The dynamic temperature profile of the tank is represented by a set of $i$ ordinary differential equations that represent the energy balance of the tank (Equation (1)). The first term is the thermal inertia of the cell. The second term is composed (from left to right) of the enthalpy flow, the thermal exchange with an eventual heat exchanger, conduction with adjacent cells and ambient losses.

$$
\begin{aligned}
A_{i} \Delta x \rho_{i} C P \frac{\mathrm{d} T_{i}}{\mathrm{~d} t}= & \dot{m}\left(h_{\mathrm{ex}, i}-h_{\mathrm{su}, i}\right)+A_{\mathrm{hx}, i} \dot{Q}_{\mathrm{hx}} \\
& +\alpha A_{i+1} \dot{Q}_{i+1}+\dot{\Omega} A_{i-1} \dot{Q}_{i-1} \\
& -A_{\mathrm{amb}, i} U\left(T_{i}-T_{\mathrm{amb}}\right) .
\end{aligned}
$$

In this equation $\alpha$ is 0 if the $i$ th node is the top of the tank and 1 otherwise and $\beta$ is 0 if the $i$ th node is the bottom node and 1 otherwise. This model is validated using experimental data under different charging and discharging conditions following prEN12977-3:2008 (CEN 2008). More details can be found in a former work (Carmo et al. 2015).

\subsection{Solar roof}

The solar roof currently installed in the house is a prototype of aluminium pipes installed on an aluminium absorber plate covered with the Alanod Miorosol coating (Innogie Aps 2013). A four millimetre thick glass surface is added to ensure the glazing (Figure A4). Commonly, thermal panels are smaller, but in this case it is more interesting to cover the whole roof $\left(138.8 \mathrm{~m}^{2}\right)$ because it is an integrated technology that acts as a solar collector and a roof. It avoids the necessity of buying a classical roof plus solar collectors (Innogie Aps 2013). Furthermore, the excess heat in summer is not wasted and can be converted into electricity through the ORC. This large roof size is classical for new buildings in the countryside of Denmark.

The heat collected from the roof is therefore modelled with Equation (2) involving the useful solar roof area $(A)$, the outdoor temperature $\left(T_{\mathrm{amb}}\right)$, the mean absorber temperature $\left(T_{\mathrm{m}}\right)$, the overall heat transfer coefficient $\left(U_{\mathrm{o}}\right)$ and the solar irradiance absorbed by a collector per unit area of absorber $(I)$.

$$
\dot{Q}_{\text {roof }}=A\left(I-U_{\mathrm{o}}\left(T_{\mathrm{m}}-T_{\mathrm{amb}}\right)\right) .
$$

The overall heat transfer coefficient $\left(U_{\mathrm{o}}\right)$ takes into account the top losses, the edge losses and the back losses. The edge losses are assumed to be zero, since the heat transfer is negligible when the collector area is higher than $30 \mathrm{~m}^{2}$ (Duffie and Beckham 2006). The back losses are also assumed to be zero due to the $400 \mathrm{~mm}$ thick insulation at the back of the collector. Finally, the top loss coefficient is evaluated using Equation (3) with a maximum error of $0.3 \mathrm{~W} / \mathrm{m}^{2}$ for mean absorber temperatures below $200^{\circ} \mathrm{C}$ (Klein 1975).

$$
\begin{aligned}
U_{T}= & \left(\frac{1}{\frac{v}{T_{m}}\left(\frac{T_{m}-T_{a}}{N+f}\right)^{e}}+\frac{1}{h_{w}}\right)^{-1} \\
& +\frac{\sigma\left(T_{m}+T_{a}\right)\left(T_{m}^{2}+T_{a}^{2}\right)}{\frac{1}{\varepsilon_{p}+s \cdot N \cdot h_{w}}+\frac{2 N+n-1+z \cdot \varepsilon_{p}}{\varepsilon_{g}}-N} .
\end{aligned}
$$


The different terms composing Equation (3) are detailed in the appendix - Table A1. The dynamic model of the solar roof finally obtained by combining Equation (2) with a thermal inertia corresponding to 104.61 of $30 \%$ volume glycol-based water solution (4).

$$
\dot{Q}_{\text {roof,inertia }}=\dot{Q}_{\text {roof }}+M_{\text {glycol }} \cdot C P_{\text {glycol }} \cdot \frac{\mathrm{d} T_{m}}{\mathrm{~d} t}
$$

\subsection{Building model}

The model is based directly on the geometry and the construction characteristics of the real Danish building. A simplified lumped parametric model is applied. The rootmean-squared error of a such a model related to inner temperature has been shown to be always lower than $1 \mathrm{~K}$ (Masy 2007). The arrangement of the different rooms of the building and the composition of the walls are taken into account. The building is first divided into five zones (dining room and kitchen, main bedroom, bathroom, hall and toilet and finally guest bedrooms. See zones definitions in Figure 2 and zone characteristics in Table A2) with constant volume, uniform temperature and conservation of mass and energy in each zone. The walls are modelled with two thermal resistances and one heat capacity, parameters being given in Masy (2007). Four inputs are added in each zone: lighting, appliances, occupancy and a thermal exchange with adjacent zones. Wind pressure and buoyancy from the air-specific volume difference and ventilation are not modelled in order to avoid too high level of complexity and computational time. Finally, the radiant slab $\left(25 \mathrm{~m}^{2}\right)$ from the buildings library (Wetter et al. 2013) is connected to the only room where it exchanges heat in the house (zone 1).

\subsection{Ground source horizontal heat exchanger (GHX)}

\subsubsection{Description of the case-study}

The ground source horizontal heat exchanger consists of three layers layout. The layers are linked in parallel and buried, respectively at $0.50,1.00$ and $1.50 \mathrm{~m}$ depth. Each layer consists of 24 tubes disposed in a head to tail setting. The tubes are made in cross-linked polyethylene and are $22.89 \mathrm{~m}$ long with a diameter of $2.6 \mathrm{~cm}$ (geometry of the GHX - Figure A5). A 30\% monoethylene glycolwater mixture is used as the heat transfer fluid. The soil is assumed to be argillaceous with a water content of $10 \%$, which corresponds to an average soil moisture (Bircher et al. 2012).

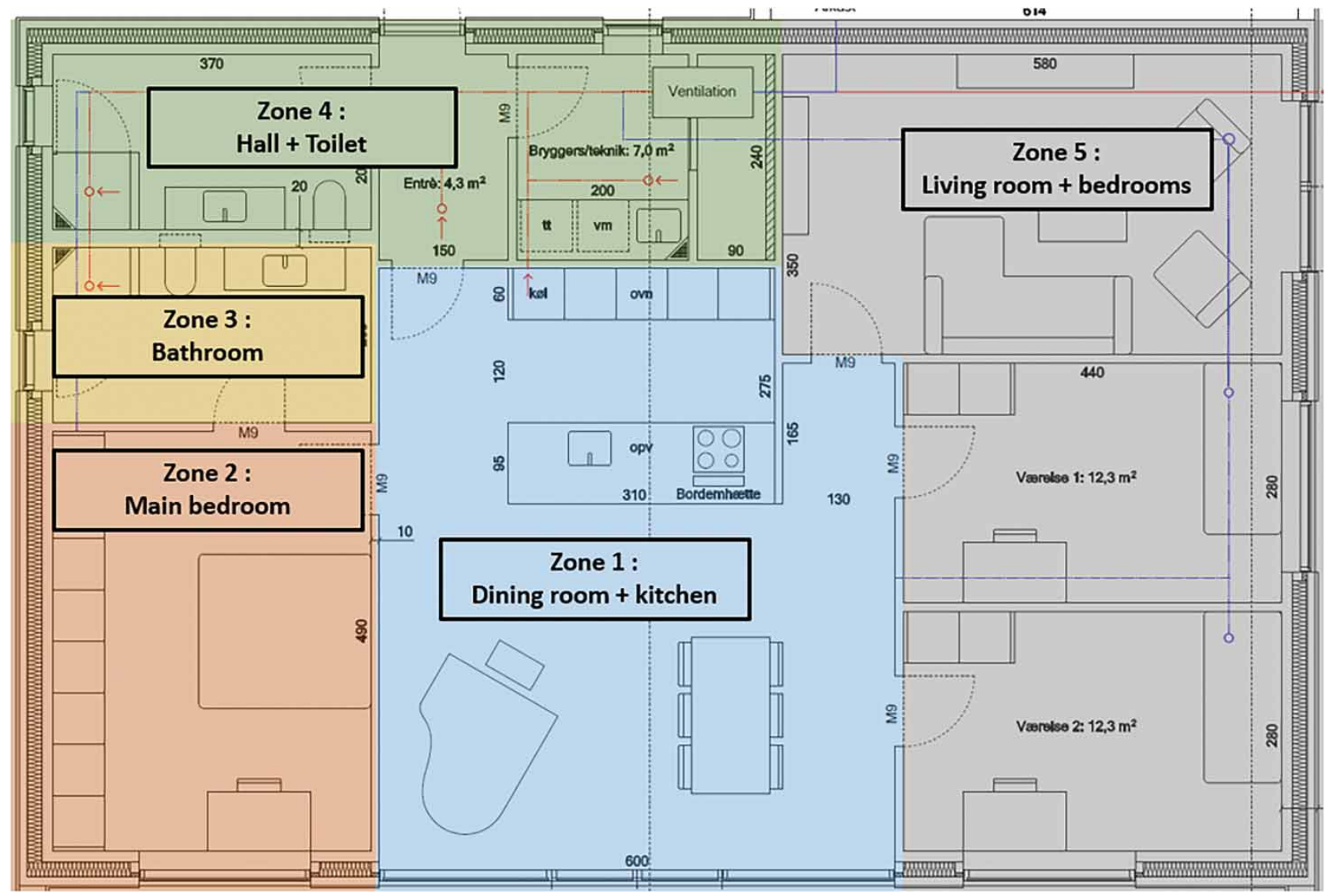

Figure 2. Division of the house into five zones. 


\subsubsection{Description of the model}

The deep earth temperature is set to $10^{\circ} \mathrm{C}$.This choice is made following ground measurements conducted in Potsdam, Germany, (PICIR 2015). The absorbance and emissivity of the soil surface are, respectively, set to 0.55 and 0.75 . An average wind speed of $4 \mathrm{~m} \mathrm{~s}^{-1}$ is considered.

A model of the ground source horizontal heat exchanger already exists (using the finite element method) in the TRNSYS simulation language (TESS 2006). A reduced-order model is developed and calibrated based on the reference finite element model (TESS 2006). This model is designed to be flexible and is valid for different kinds of pipes geometry and layout.

The model consists in discretizing three layers of ground (Figure 3 ). The central element in the model is the

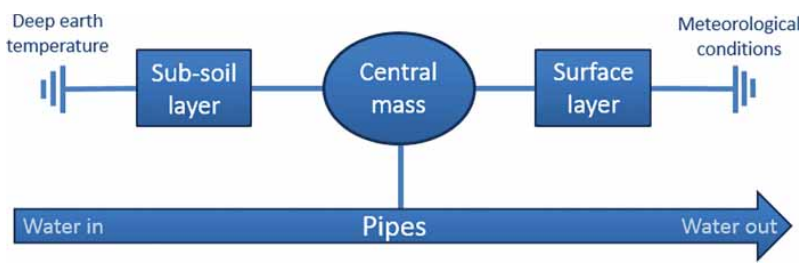

Figure 3. Layout of the reduced-order model of the horizontal ground heat exchanger.

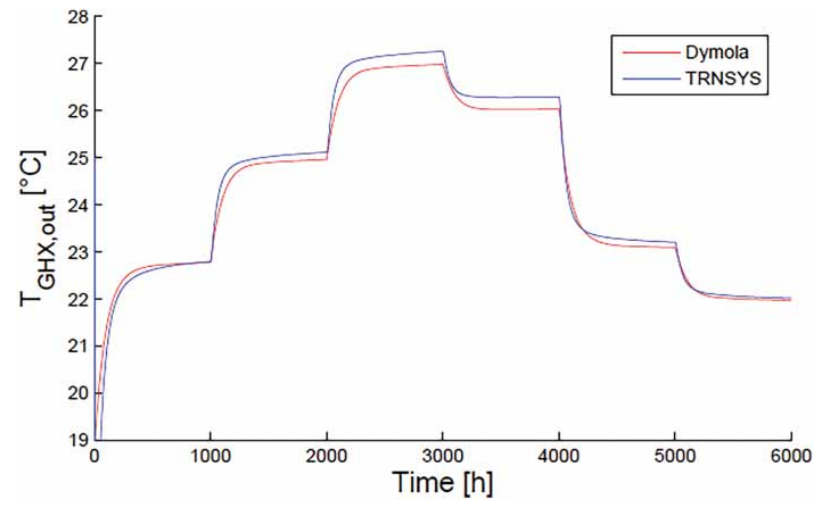

Figure 4. Water outlet temperature of the ground heat exchanger submitted to step inputs: Finite-element model (Trnsys) versus reduced-order model (Dymola). soil central thermal mass which simulates the soil directly surrounding the GHX pipes. In addition, a surface layer which reacts rapidly to climate variations (solar irradiation, ambient temperature and sky temperature) is added. Finally, a sub-soil layer presenting slow variations through the seasons is modelled and connected to the deep earth temperature. Each layer is modelled with a central capacity and two resistors. The pipes are modelled with a finitevolume 1D flow model (20 cells) from the Thermocycle library (Quoilin et al. 2014). Finally, two thermal resistors are added to the pipes to account for the resistance of the tube and, for the resistance of the soil.

\subsubsection{Calibration of the reduced-order model}

The reduced-order model described here above is calibrated with the finite element model as a reference by variation of the two main inputs, which are the ambient temperature and the solar irradiation. The GHX model parameters are defined in Table A3 (in the appendix). With these parameters, results show good agreement between the two models. A maximum deviation of $0.5 \mathrm{~K}$ is observed for the prediction of the water outlet temperature (Figure 4).

\subsection{Global model}

Figure 5 presents the flowchart of the global model combining the storage, the building, the roof, the reversible unit and the ground heat exchanger. Hourly schedules are associated with the occupancy, the DHW use, the lighting and appliances in each zone (Georges et al. 2013). The weather data used for the outdoor temperature and the solar irradiance are provided by the DMI - Danish Meteorological Institute - (Wang et al. 2010) in the case of Denmark and by Energy Plus Energy Simulation Software (EnergyPlus 2015) for other locations. An adaptive time step is computed by the solver, but is not allowed to exceed $900 \mathrm{~s}$. A low time step induces too much computational time and too large output file size, a time step larger than $20 \mathrm{~min}$ could lead to errors larger than 5\% (Bouvenot et al. 2015). The typical computational time is $3 \mathrm{~h}$ for an annual simulation. The consumption of auxiliary pumps (except GHX

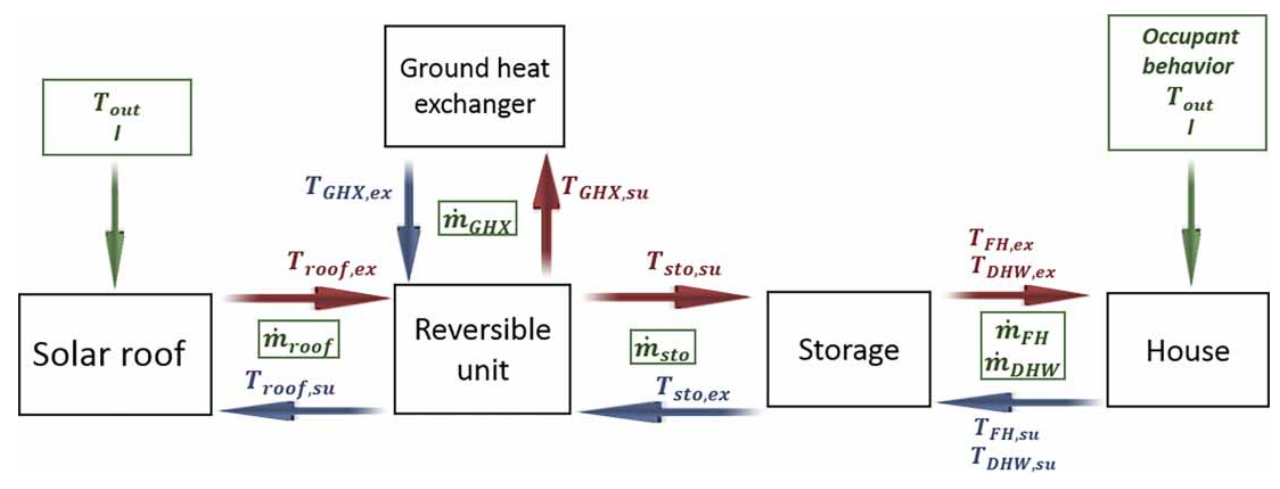

Figure 5. Global model and connections between sub-models. 
pump) is neglected, they represent less than $2 \%$ of the global system power consumption.

Some parameters have to be fixed: roof water flow rate, ground heat exchanger water flow rate, and storage water flow rate and temperature set-points of the storage. Practically, the following values are used for the flow rates based on real values imposed in the house:

- Roof water flow rate $=0.6 \mathrm{~kg} \mathrm{~s}^{-1}$,

- Ground heat exchanger water flow rate $=1.5 \mathrm{~kg} \mathrm{~s}^{-1}$,

- Storage water flow rate $=0.6 \mathrm{~kg} \mathrm{~s}^{-1}$

These flow rates should be optimized in future investigations to increase the energy efficiency of the system (Burhenne et al. 2013).

\subsection{Control}

The control strategy ensures that the heat demand is covered while electricity is produced with the surplus of heat. For this reason the first control variable used is the hot water storage tank temperature (the control temperature point is located at mid-height of the tank).

A state diagram control is implemented. The conditions governing the transitions between the three modes (HP, $\mathrm{ORC}$ and $\mathrm{DH}$ ) and the stand-by mode (Bypass) are shown in Figure 6. The Bypass mode means that no HP, ORC or DH is activated, only the FH circuit can be activated extracting energy from the water store, if necessary, to reach the desired indoor conditions $\left(20^{\circ} \mathrm{C}\right)$. The principle is the following: if the storage is too cold (the control temperature of the storage is lower than the low-temperature threshold), the HP mode is activated. If the roof temperature is higher than the storage one, the DH mode is used. Finally, the ORC system produces electricity when the storage temperature has reached a given high threshold and if a stable state can be reached. This means that the ORC is only activated once it can produce a certain level of power $\left(W_{\mathrm{ORC}, \min }\right)$. The $W_{\mathrm{ORC} \text {, min }}$ is used to enable a smooth and efficient operation of the system in ORC mode. When a stable operation of the ORC cannot be guaranteed $\left(W_{\text {ORC }}<W_{\text {ORC,min }}\right)$, the TES is allowed to go above the high-temperature threshold. It should be noted that the HP mode, is using either the roof or the horizontal ground heat exchanger depending on which one is the warmest.

Table 1 summarizes the values of each threshold temperature. The threshold values were chosen to avoid chattering (too many mode changes) and to maximize the efficiency of the system in Dumont, Quoilin, and Lemort (2014). The number of mode changes is considered high when more than one change occurs in a 15 -min period.

It should be noted that, although the set-points and thresholds have been optimized, the proposed control strategy is still a myopic rule-based control strategy. A truly

Table 1. Values of the temperature thresholds.

\begin{tabular}{|c|c|c|}
\hline Temperature threshold & Abbreviation & Value \\
\hline $\begin{array}{l}\text { High-temperature threshold of } \\
\text { the storage }\end{array}$ & $T_{\text {sto }, \mathrm{h}}\left({ }^{\circ} \mathrm{C}\right)$ & 50 \\
\hline $\begin{array}{l}\text { Low-temperature threshold of } \\
\text { the storage }\end{array}$ & $T_{\text {sto }, 1}\left({ }^{\circ} \mathrm{C}\right)$ & 40 \\
\hline Power threshold of the ORC & $W_{\mathrm{ORC}, \min }(W)$ & 2000 \\
\hline Indoor comfort temperature & $T_{\text {in }}\left({ }^{\circ} \mathrm{C}\right)$ & 20 \\
\hline
\end{tabular}

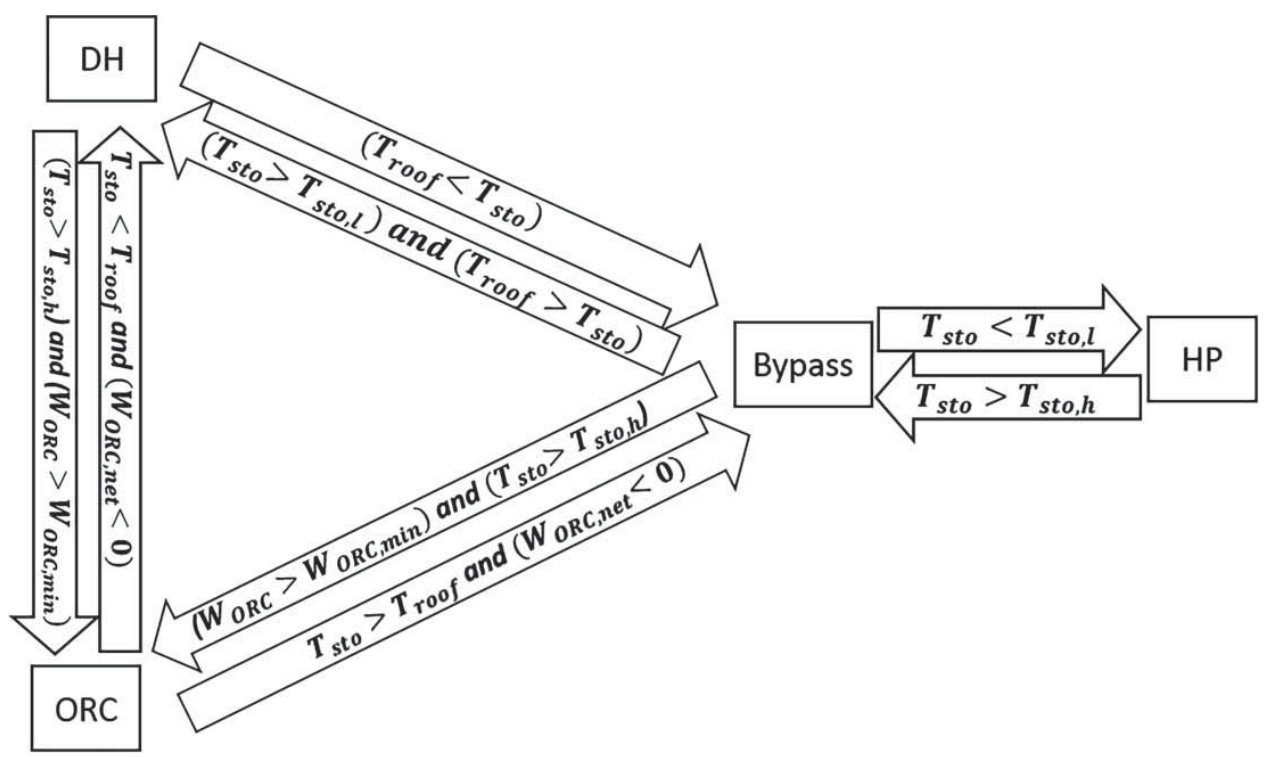

Figure 6. State diagram control. $T_{\text {roof }}$ is the roof exhaust temperature, $T_{\text {sto }}$ is the storage control temperature (middle height of the tank), $T_{\text {sto,l }}$ is the low-temperature threshold of the storage, $T_{\text {sto,h }}$ is the high-temperature threshold of the storage, $W_{\mathrm{ORC}, \mathrm{min}}$ is the minimum power to start the ORC system. 
optimal control strategy is difficult to implement because of the high number of manipulated variables, the numerous set-points and the non-linearity of the problem. It would require a predictive nonlinear optimization, based on the next $24 \mathrm{~h}$ of weather forecast, user behaviour and electricity prices. Such approach would avoid, for example, starting the HP when the solar heat will be sufficient to cover the heat demand later in the day.

\subsection{Performance criteria}

Yearly simulations are performed and evaluated through the following performance criteria:

- Gross electrical production (Wh): the energy produced by the ORC (or the PV panels if specified) ( $\left.W_{\text {el,prod }}\right)$.

- HP electrical consumption (Wh): the electrical consumption of the HP $\left(W_{\mathrm{el}, \mathrm{HP}}\right)$.

- Gross electrical consumption (Wh): the sum of appliances, lighting and HP electrical consumption.

- Net electrical production (Wh): the gross electrical production minus the gross electrical consumption $\left(W_{\text {el,net }}\right)$.

- The total thermal energy production of the unit, includes both thermal production from HP and solar thermal roof collector $(\mathrm{Wh})\left(Q_{\mathrm{th}, \mathrm{prod}}\right)$.

- DH energy (Wh): the total thermal energy gained by means of the DH mode $\left(Q_{\mathrm{DH}}\right)$.

- B, Benefits $(€)$ : the income benefits evaluated following the Danish law (Equation (5)). It does not take any investment into account. $\dot{W}_{\mathrm{HP}}$ is the electrical power consumption of the HP. $\dot{W}_{\text {net }}$ is the net electrical power, i.e. the electrical production minus the electrical power consumption of lighting and appliances. $P_{r} \sim 0.28 € \mathrm{~W}^{-1} \mathrm{~h}^{-1}$ is the retail price considered when the net electrical power is negative, $P_{r, \mathrm{HP}}$ is the retail price for the HP only $\sim 0.22 € \mathrm{~W}^{-1} \mathrm{~h}^{-1}$ and $P_{\mathrm{bb}}$ is the buy-back tariff $\sim$ $0.17 € \mathrm{~W}^{-1} \mathrm{~h}^{-1}$ considered when the net electrical power $\left(\dot{W}_{\text {net }}\right)$ is positive. Retail and buy-back tariffs are provided by real data from Denmark (Energinet 2015).

$$
\text { If } \begin{aligned}
\dot{W}_{\text {net }}>0 \text { then } B & =\int_{0}^{t}\left(P_{\mathrm{bb}}\left(\dot{W}_{\text {net }}\right)-P_{r, \mathrm{HP}} \cdot \dot{W}_{\mathrm{HP}}\right) \cdot \mathrm{d} t \\
\text { else } B & =\int_{0}^{t}\left(P_{r}\left(\dot{W}_{\text {net }}\right)-P_{r, \mathrm{HP}} \cdot \dot{W}_{\mathrm{HP}}\right) \cdot \mathrm{d} t .
\end{aligned}
$$

- Supply cover factor or self-production rate $\left(\gamma_{S}\right)$, which represents the fraction of energy produced by the ORC (or PV) which is used to cover instantaneous electrical consumption (Equation (6)) (Baetens et al. 2012).

$$
\gamma_{S}=\frac{\sum \min \left(W_{\text {cons. }}, W_{\text {prod }}\right)}{\sum W_{\text {prod }}} .
$$

- Demand cover factor or self-consumption rate $\left(\gamma_{d}\right)$, which represents the fraction of energy consumption which has been produced by the ORC (or PV) (Equation (7)).

$$
\gamma_{D}=\frac{\sum \min \left(W_{\text {cons. }}, W_{\text {prod }}\right)}{W_{\text {cons. }}} .
$$

For all the simulations in this paper, the set-points temperature of the storage, the set-point in the main room of the building and the solar roof are the same.

\section{Simulation of typical days}

The system response is presented for three characteristic days in Denmark: a winter day (day 1), a spring day (day 62 ) and a summer day (day 182). Eight variables are analysed in this section: the storage control temperature $\left(T_{\text {sto }}\right)$, the outdoor temperature $\left(T_{\text {out }}\right)$, the house ambient temperature in zone $1\left(T_{\text {in }}\right)$, the exhaust roof temperature $\left(T_{\text {roof }}\right)$, the ground heat exchanger exhaust temperature $\left(T_{\mathrm{GHX}}\right)$, the heat flow rate for $\mathrm{FH}\left(\dot{Q}_{\mathrm{FH}}\right)$, the heat flow rate for DHW ( $\left.\dot{Q}_{\text {DHW }}\right)$, the heat flow rate from the reversible unit or from the solar roof $\left(\dot{Q}_{\text {th,prod }}\right)$ and the electrical unit power consumption $(-) /$ production $(+)\left(\dot{W}_{\mathrm{el}}\right)$.

\subsection{Winter - Day 1}

The behaviour of the system is plotted in Figure 7 for a characteristic winter day. Slightly after 4., the FH is activated $\left(\dot{Q}_{\mathrm{FH}}\right)$ in a way to keep the indoor temperature $\left(T_{\text {in }}\right)$ close to $20^{\circ} \mathrm{C}$. This leads to a decrease in the control temperature of the storage $\left(T_{\text {sto }}\right)$ down to the lower temperature threshold of $40^{\circ} \mathrm{C}$. The HP mode is therefore activated to raise the control temperature of the storage up to the high-temperature threshold of the storage $\left(50^{\circ} \mathrm{C}\right)$. This phenomenon is observed three times during this day (4., 14 and 20). The heat generated in HP mode is $\dot{Q}_{\mathrm{HP} / \mathrm{ORC}}$ and corresponds to an electrical power of $\dot{W}_{\mathrm{el}}$. The DH mode cannot be activated because of the low temperature of the water in the roof $\left(T_{\text {roof }}\right)$. In this case, the system is acting as a classical ground source HP during this representative winter day.

\section{2. $\quad$ Spring - Day 62}

A typical spring day is depicted in Figure 8. First, around 3 , the FH starts, decreasing the storage control temperature. Thus, the HP is activated following the same scheme as for the typical winter day. The difference is that around $10 \mathrm{~h} 30 \mathrm{~min}$, the roof exhaust temperature is higher than the storage temperature and the system can therefore benefit from DH until the next day. In that case, the DH allows to start the HP mode only once during day 62 to cover the heat demand of the building. 

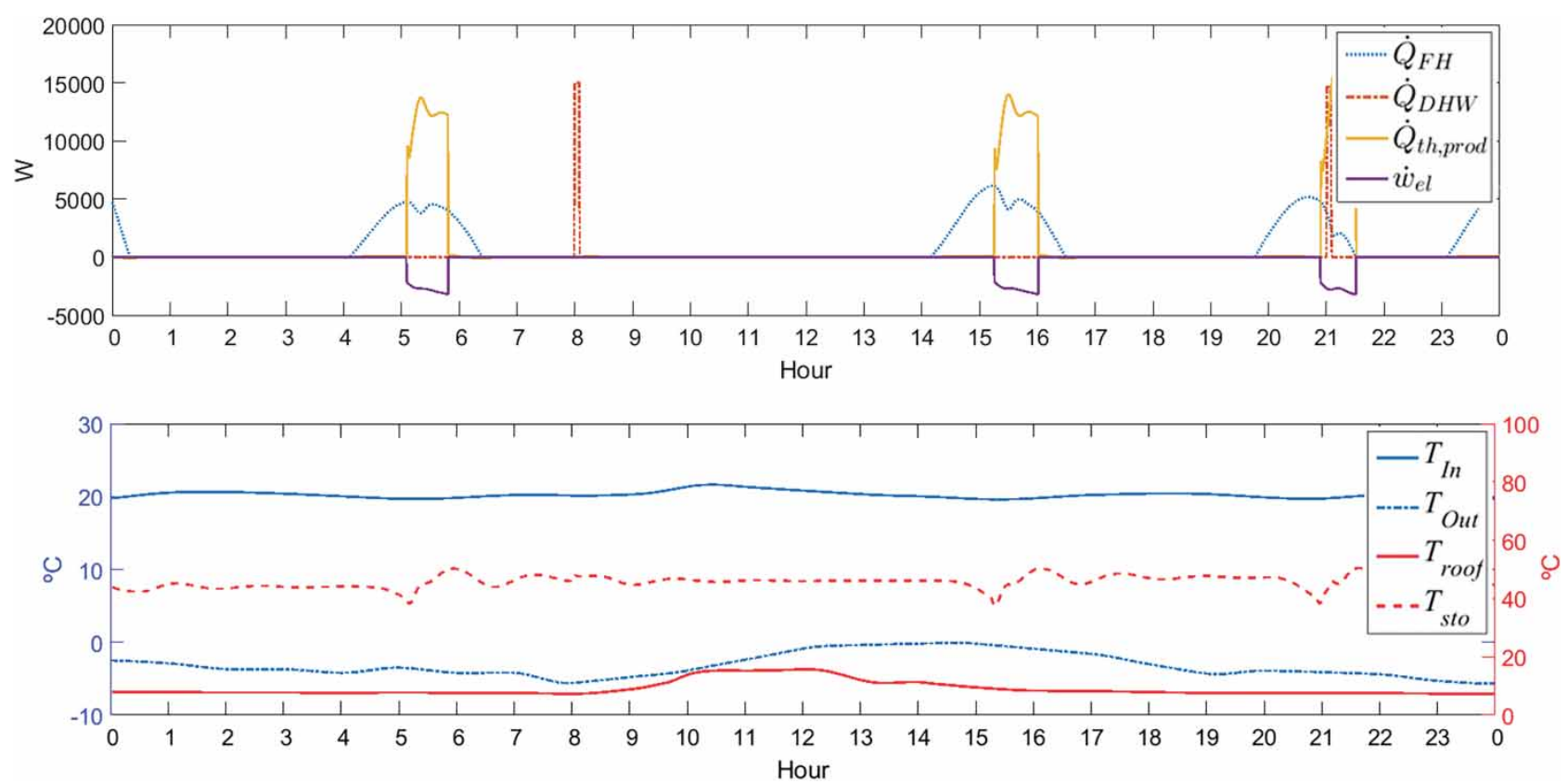

Figure 7. Dynamic simulation of the reversible unit coupled to a passive house for the first day of the year.
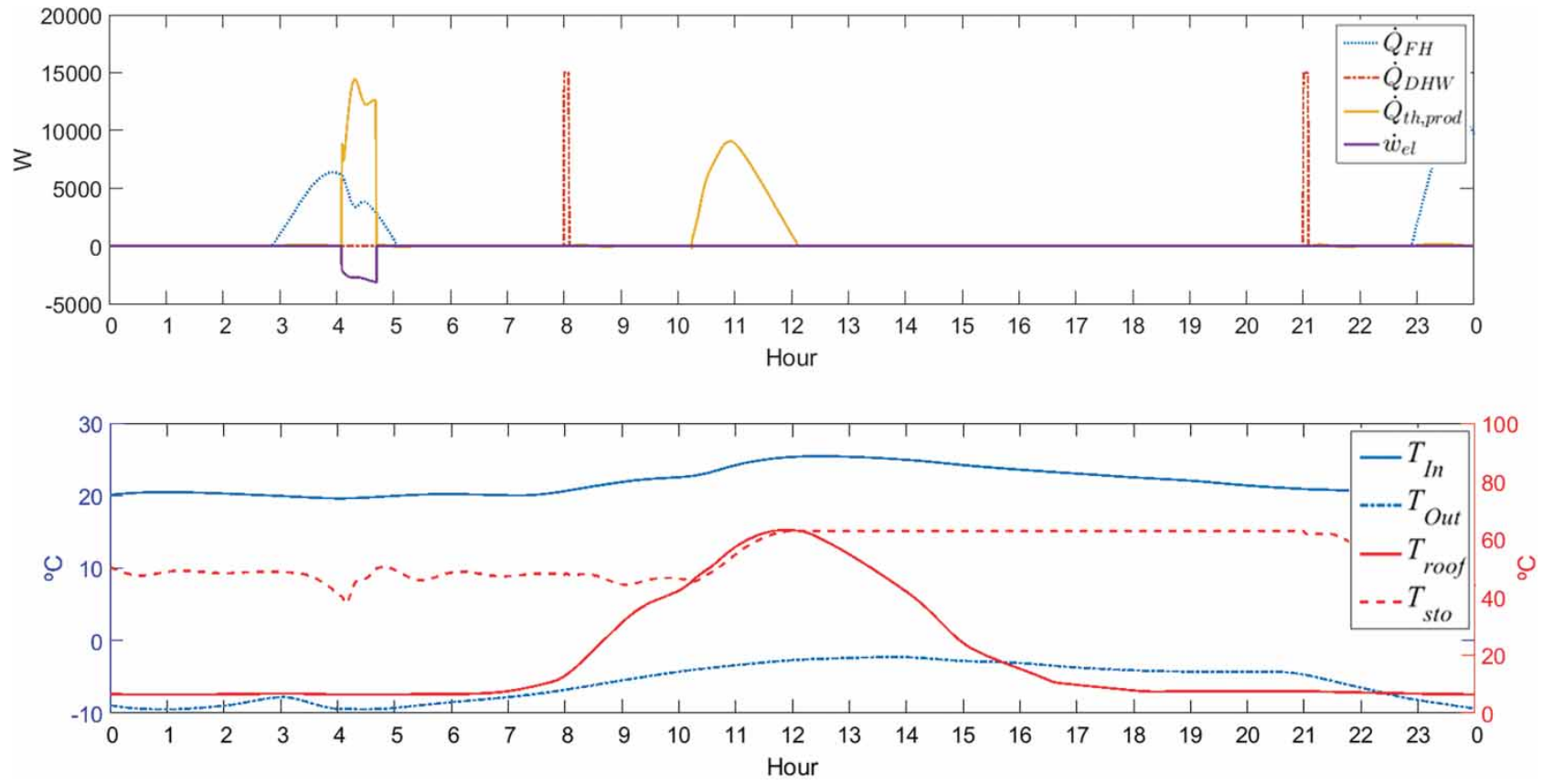

Figure 8. Dynamic simulation of the reversible unit coupled to a passive house for the 62 nd day of the year.

\subsection{Summer - Day 182}

Figure 9 presents the response of the reversible unit for a characteristic summer day for the study case in Denmark. Slightly before 8 the DH mode is activated since the roof temperature becomes higher than the storage temperature. When the storage temperature reaches its maximum value, the ORC mode can be activated to generate electricity. The electrical production of the ORC is low (compared to the nominal power, $5290 \mathrm{~W}$ ) due to the high temperature of the water in the GHX. Since the heat demand is rather small (no FH, only DHW) and the capacity of the storage is hot enough there is no need to heat the thermal energy store. The ORC mode is therefore activated as long as the electrical production is greater than zero. 

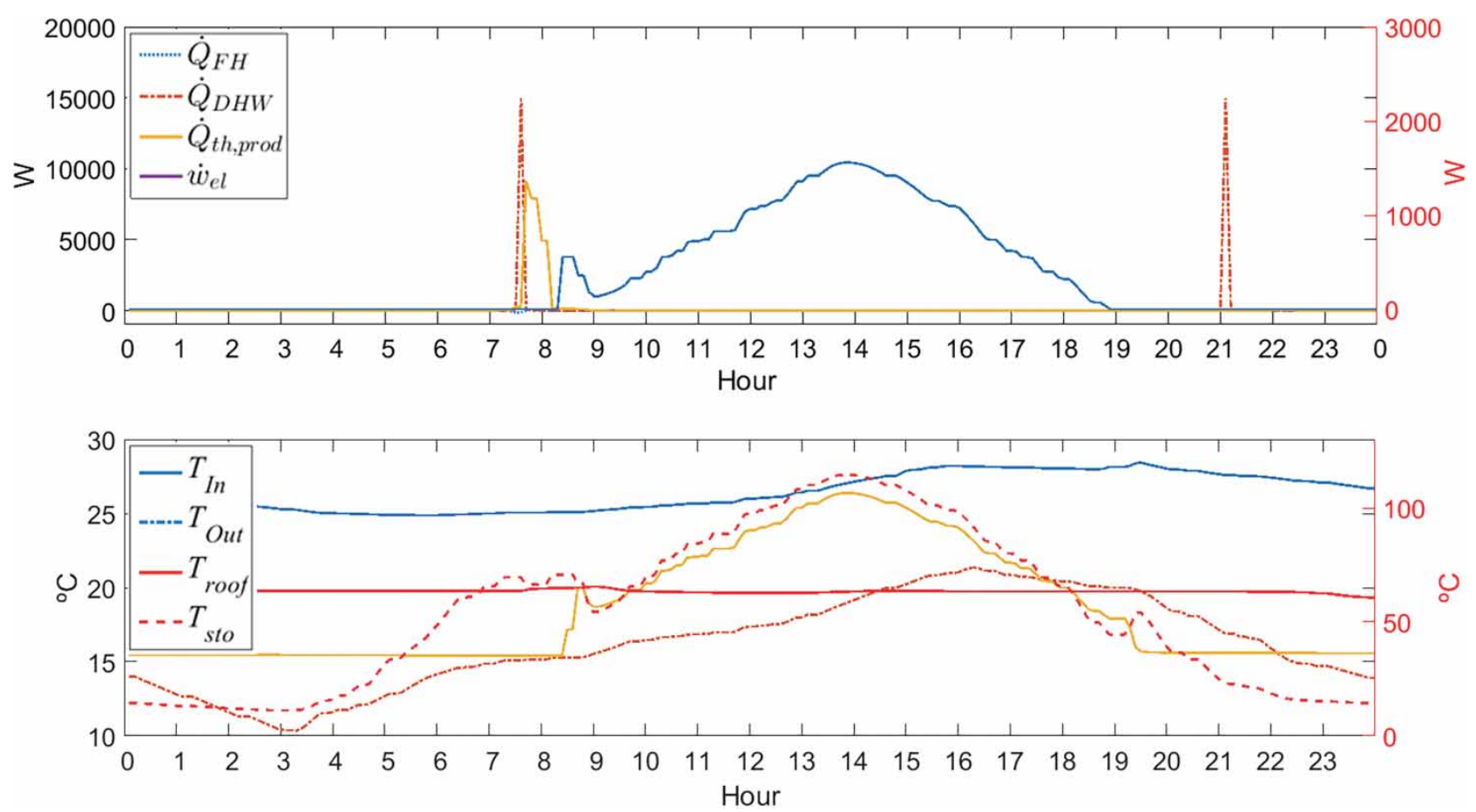

Figure 9. Dynamic simulation of the reversible unit coupled to a passive house for the 182 nd day of the year. Mode 1 is ORC, mode 2 is direct heating and mode 3 is heat pump.

\section{Annual performance}

\subsection{Reference case}

First, before establishing a sensitivity analysis, a basic case yearly simulation corresponding to the real conditions of the house located in Herning, Denmark, is performed. In this simulation, there is one thermal storage of 5001 for DHW and FH. Figure 10 presents a comparison of the electrical ORC production, HP electrical consumption and thermal energy provided by the DH mode for each month of the year. The HP is running during 5 months of the year, mainly in winter, leading to a total electricity consumption of $827 \mathrm{kWh}_{\mathrm{e}}$ and heat supply of $3082 \mathrm{kWh}_{\mathrm{th}}$. DH is used 10 months of the year and produces $1207 \mathrm{~kW}_{\text {th }}$, representing $28.1 \%$ of the total heat demand of the building during a year.

\section{Energy along a year}

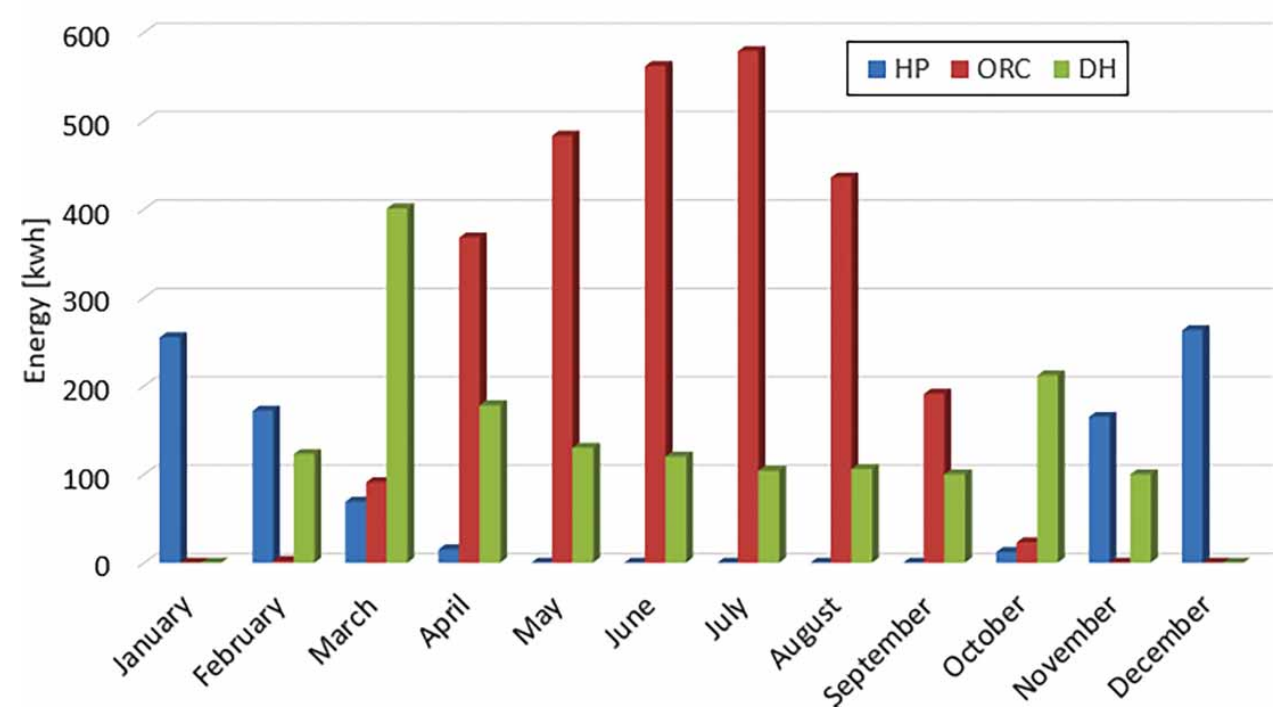

Figure 10. Comparison of the heat pump electrical consumption, electrical ORC production and thermal energy provided by the direct heating mode for each month of the year in the reference case. 
The DH mode is less used in summer months compared to March and October because the heat demand for FH is significantly lower. The gross electrical ORC production is equal to $3012 \mathrm{kWh}_{\mathrm{e}}$, the lighting and appliances consumption reaches $1491 \mathrm{kWh}_{\mathrm{e}}$, leading to a net electrical production of $694 \mathrm{kWh}_{\mathrm{e}}$ on a yearly basis. This demonstrates the ability of the current technology to get a PEB in terms of electricity use. Using Equation (3), the annual running costs of the system in aforementioned conditions are $119 €$.

\subsection{Results of the sensitivity analysis on the performance of the HP/ORC system}

After considering the basic case, it is interesting to compare the system behaviour resulting from different climates. A former project (Knight et al. 2010) has shown that European climate can be divided into five different typical zones. The system is therefore simulated for five cities located in each zone (from north to south): Copenhagen, Frankfurt, Torino, Rome and Palermo. For comparison purposes, the feed-in tariffs for the different locations were maintained as in the Danish case.

Secondly, two additional different building envelope characteristics - K15 and K30 (Masy et al. 2015) are studied in all climates. They differ in terms of coefficient of heat transmission and air tightness (see appendix - Table A4). Finally - as proposed in Georges et al. (2013) - two additional Light and Appliances profiles (L\&A) are simulated with the reference Danish building characteristics. The latter differ in the magnitude of power demand. In descending order of magnitude, L\&A 2010 $(3000 \mathrm{kWh} /$ year) is characterized by highest demand, followed by L\&A $2030(2000 \mathrm{kWh} /$ year) and L\&A Danish $(1491 \mathrm{kWh} /$ year). Table 2 shows the results of sensitivity analysis on the performance of the HP/ORC system under different conditions of climate, insulation and lights and appliances demand according to the performance parameters listed in Section 2.9 Performance criteria.

From Table 2, it can be concluded that for any building and light and appliances demand sunniest locations (south Europe) leads to higher power production and thus, higher financial benefits. On the other hand, the HP is almost never used in southern locations, because the heat demand is small and, therefore can benefit from the DH. On the contrary, northernmost locations present low heat energy provided by $\mathrm{DH}$. There is an optimal location in latitude close to Torino that shows the best compromise to benefit optimally of the thermal energy from the DH. It is interesting to note that an increase in lights and appliances demand - in all locations - not only decreases the

Table 2. Results of the sensitivity analysis.

\begin{tabular}{|c|c|c|c|c|c|c|c|c|c|c|}
\hline Building & L\&A & Location & $\begin{array}{c}Q_{\text {th,prod }} \\
(\mathrm{kWh})\end{array}$ & $\begin{array}{c}W_{\text {el,prod }} \\
(\mathrm{kWh})\end{array}$ & $\begin{array}{l}W_{\mathrm{el}, \mathrm{hp}} \\
(\mathrm{kWh})\end{array}$ & $W_{\text {net }}(\mathrm{kWh})$ & Benefits (€) & $\gamma_{\mathrm{s}}$ & $\gamma_{\mathrm{D}}$ & $Q_{\mathrm{dh}}(\mathrm{kWh})$ \\
\hline \multirow[t]{15}{*}{ Danish } & \multirow[t]{5}{*}{2010} & Copenhagen & 3597 & 3015 & 690 & -675 & -501 & 0.13 & 0.13 & 1057 \\
\hline & & Frankfurt & 3291 & 3609 & 572 & 37 & -368 & 0.119 & 0.14 & 1180 \\
\hline & & Torino & 2243 & 5379 & 189 & 2190 & 38 & 0.1 & 0.18 & 1523 \\
\hline & & Roma & 1072 & 6646 & 16 & 3630 & 312 & 0.1 & 0.23 & 990 \\
\hline & & Palermo & 861 & 8597 & 0 & 5597 & 666 & 0.096 & 0.27 & 845 \\
\hline & \multirow[t]{5}{*}{ Danish } & Copenhagen & 4289 & 3012 & 827 & 694 & -119 & 0.071 & 0.138 & 1207 \\
\hline & & Frankfurt & 3879 & 3607 & 699 & 1417 & 15 & 0.065 & 0.15 & 1292 \\
\hline & & Torino & 2700 & 5371 & 251 & 3629 & 422 & 0.054 & 0.185 & 1726 \\
\hline & & Roma & 1301 & 6639 & 35 & 5113 & 695 & 0.053 & 0.226 & 1148 \\
\hline & & Palermo & 889 & 8597 & 0 & 7106 & 1046 & 0.049 & 0.27 & 872 \\
\hline & \multirow[t]{5}{*}{2030} & Copenhagen & 4025 & 3014 & 783 & 231 & -260 & 0.093 & 0.133 & 1134 \\
\hline & & Frankfurt & 3652 & 3609 & 647 & 962 & -125 & 0.084 & 0.145 & 1254 \\
\hline & & Torino & 2545 & 5374 & 226 & 3148 & 281 & 0.071 & 0.181 & 1671 \\
\hline & & Roma & 1211 & 6643 & 26 & 4617 & 553 & 0.07 & 0.22 & 1088 \\
\hline & & Palermo & 875 & 8596 & 0 & 6596 & 904 & 0.065 & 0.26 & 859 \\
\hline \multirow[t]{5}{*}{ K15 } & \multirow[t]{5}{*}{ Danish } & Copenhagen & 2887 & 3021 & 535 & 995 & -38 & 0.047 & 0.096 & 912 \\
\hline & & Frankfurt & 2685 & 3615 & 447 & 1677 & 81 & 0.042 & 0.1 & 1034 \\
\hline & & Torino & 1772 & 5386 & 120 & 3775 & 464 & 0.036 & 0.131 & 1304 \\
\hline & & Roma & 980 & 6648 & 12 & 5145 & 708 & 0.036 & 0.159 & 917 \\
\hline & & Palermo & 863 & 8596 & 0 & 7105 & 1048 & 0.033 & 0.19 & 847 \\
\hline \multirow[t]{5}{*}{ K30 } & \multirow[t]{5}{*}{ Danish } & Copenhagen & 8667 & 2987 & 1723 & -227 & -318 & 0.046 & 0.092 & 2031 \\
\hline & & Frankfurt & 7804 & 3573 & 1457 & 625 & -156 & 0.041 & 0.098 & 2206 \\
\hline & & Torino & 5956 & 5334 & 803 & 3040 & 300 & 0.035 & 0.128 & 2837 \\
\hline & & Roma & 3254 & 6585 & 196 & 4898 & 655 & 0.035 & 0.155 & 2468 \\
\hline & & Palermo & 1670 & 8562 & 15 & 7056 & 1038 & 0.032 & 0.187 & 1586 \\
\hline
\end{tabular}

Notes: $\left(Q_{\text {th,prod }}\right.$ is the total thermal energy production of the HP/ORC unit, in both HP and DH mode, $W_{\text {el,prod }}$ is the gross electrical production, $W_{\mathrm{el}, \mathrm{HP}}$ is the HP electrical consumption, $W_{\mathrm{el}, \text { net }}$ is the net electrical production). $B$ are the income benefits, $\gamma_{S}$ is the selfproduction rate, $\gamma_{d}$ is the self-consumption rate and $Q_{\mathrm{DH}}$ is the $\mathrm{DH}$ energy. 
net power output and benefits, but also decreases the HP power consumption. This is due to the internal heat gains by means of light and appliances, which decrease the heating demand. On the other hand, it is shown that lower levels of insulation lead to higher heating demand covered by $\mathrm{DH}$ without compromising the ORC power output and the financial benefits.

\subsection{Comparison with a HP combined with photovoltaic panels}

In a former article (Dumont et al. 2015), a performance comparison between the HP/ORC reversible unit and a classical mature alternative solution for PEBs which consists of photovoltaic panels combined with a water-to-water heat pump (HP/PV) is performed. Another alternative single-technology capable of delivering heat and electric power is PVT but it is considered out of the scope of this study (He et al. 2006; Herrando, Markides, and Hellgardt 2014 and Dupeyrat, Ménézo, and Fortuin 2014). In this former paper (Dumont et al. 2015), the area of photovoltaic panel is fixed in a way that the electrical peak power is the same as the HP/ORC reversible unit in typical nominal summer conditions to get comparable results. It is shown that, the best system is always the $\mathrm{HP} / \mathrm{PV}$ system in terms of electrical production, income benefits and matching of the production and consumption. Nevertheless, an interesting advantage of the reversible unit is the lower HP electrical consumption which makes this system more profitable if no electricity can be bought from the grid (isolated network for example). Furthermore, an economic feasibility study of the total cost (income benefit and investment) of the HP/ORC system is compared to the cost of the HP/PV system. The reversible system is never profitable in the base case, i.e. with a heat demand corresponding to the real house. But, if the heat demand is significantly higher (8 times higher DHW consumption) the reversible unit is much more profitable.

\section{Conclusion}

The recent interest for PEBs has led to development of new technologies and solutions. In this paper, a reversible HP/ORC coupled to a passive house is studied. This technology is a promising option to achieve a PEB. The modelling of each sub-system (ground heat exchanger, thermal energy storage, building, solar roof, reversible HP/ORC unit) and the control strategy are described extensively. Simulations show that this technology leads to a PEB on an annual basis. Moreover, a sensitivity study has led to the following conclusions:

- The HP/ORC system presents a positive net electrical production while covering the total heat demand of the building over a year, even in cold climates such as that of Denmark. The results show that, in the Danish case-study of a single-family house with a $138.8 \mathrm{~m}^{2}$ solar collector, the electrical production by the ORC system yields $3012 \mathrm{kWh} /$ year while the total annual electrical consumption is $2318 \mathrm{kWh} /$ year.

- The climate in southernmost cities is much more favourable for the ORC system because it works for longer periods and closer to its nominal conditions.

- There is an optimum location (for latitudes around Torino) where the DH is maximum.

- A low insulation of the building and/or a low energy lighting and appliances profile leads to a better use of the system, benefiting from more energy from $\mathrm{DH}$.

- When compared to a HP coupled with PV panels, results show that the HP/ORC unit could only be profitable in the case of a large heat demand of the building and/or restriction on buying electricity from the grid. More generally, this means that buildings with a high heat demand, everything else being constant, are profitable for the reversible unit. A large building or a building with high DHW consumption could fit this constraint (office building, hospital, prison, stadium, etc.).

\section{Acknowledgements}

This work was supported and funded by the Eurostars Program (Single HPA Unit).

\section{Nomenclature}

Variables

A $\quad$ area $\left(\mathrm{m}^{2}\right)$

$\mathrm{B} \quad$ income benefits $(€)$

COP coefficient of performance $(-)$

$\mathrm{CP} \quad$ specific heat capacity at constant pressure $(\mathrm{J} /(\mathrm{kg} \mathrm{K}))$

$e \quad$ empirical variable used in the roof model $(-)$

$f \quad$ factor $(-)$

$h \quad$ specific enthalpy $(\mathrm{J} /(\mathrm{K} \mathrm{kg}))$

$i \quad$ index (-)

I irradiance $\left(\mathrm{W} \mathrm{m}^{-2}\right)$

$M \quad \operatorname{mass}(\mathrm{kg})$

$\dot{m} \quad$ mass flow rate $(\mathrm{kg} / \mathrm{s})$

$N \quad$ number of plates $(-)$

$P \quad \operatorname{cost}\left(€ . \mathrm{W}^{-1} \mathrm{~h}^{-1}\right)$

$\dot{Q} \quad$ heat transfer (W)

$r \quad$ interest rate (\%)

$s \quad$ empirical constant (-)

$t \quad$ time (s)

$T \quad$ temperature $\left({ }^{\circ} \mathrm{C}\right)$

$U$ heat transfer coefficient $\left(\mathrm{W} \mathrm{m}^{-2} \mathrm{~K}^{-1}\right)$

$v \quad$ empirical constant used in the roof model ( - )

$W \quad$ energy (Wh)

$\dot{\mathrm{W}} \quad$ Power (W)

$x \quad$ length $(\mathrm{m})$

$y \quad$ empirical constant $(-)$

$z \quad$ empirical constant $(-)$

Greek symbols

$\eta \quad$ efficiency $(-)$

$\alpha \quad$ numeric coefficient $(-)$ 


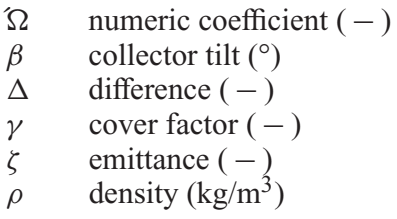

Abbreviations

$\begin{array}{ll}\text { CHP } & \text { combined heat and power } \\ \text { GHX } & \text { Horizontal ground heat exchanger } \\ \text { HP/ORC } & \text { Reversible HP/ORC unit } \\ \text { HP/PV } & \text { HP combined with PV } \\ \text { NZEB } & \text { Net Zero Energy Building } \\ \text { PV } & \text { Photovoltaic panels }\end{array}$

Subscripts

$\begin{array}{ll}\text { amb } & \text { ambient } \\ \mathrm{b} & \text { back } \\ \mathrm{bb} & \text { buy-back } \\ \mathrm{BH} & \text { Borehole } \\ \text { cons } & \text { consumption } \\ \mathrm{D} & \text { demand } \\ \text { ex } & \text { exhaust } \\ \mathrm{FH} \text { (floor) } & \text { floor heating } \\ \text { glycol } & \text { Glycol } \\ \mathrm{HGHE} & \text { horizontal ground heat exchanger } \\ \mathrm{h} & \text { high } \\ \mathrm{hx} & \text { exchanger } \\ \text { in } & \text { indoor } \\ \text { Inertia } & \text { Inertia } \\ \mathrm{l} & \text { low } \\ \text { l-a } & \text { lighting and appliances } \\ \mathrm{m} & \text { mean } \\ \text { match } & \text { matching } \\ \text { min } & \text { minimum } \\ \text { net } & \text { Net } \\ \mathrm{p} & \text { plate } \\ \text { prod } & \text { production } \\ \mathrm{O} & \text { Overall } \\ \text { out } & \text { outdoor } \\ \mathrm{r} & \text { retail } \\ \text { roof } & \text { solar roof } \\ \mathrm{S} & \text { supply } \\ \text { sto } & \text { storage } \\ \text { su } & \text { supply } \\ \mathrm{T} & \text { top } \\ \end{array}$

\section{References}

Baetens, R., R. De Coninck, J. Van Roy, B. Verbruggen, J. Driense, L. Helsen, and D. Saelens. 2012. "Assessing Electrical Bottlenecks at Feeder Level for Residential Net Zero-Buildings by Integrated System Simulation." Applied Energy 96: 74-83.

Bircher, S., N. Skou, K. H. Jensen, J. P. Walker, and L. Rasmussen. 2012. "A Soil Moisture and Temperature Network for SMOS Validation in Western DK." Hydrology and Earth System Sciences 16: 1445-1463.

Bouvenot, J.-B., M. Siroux, B. Latour, and B. Flament. 2015. "Dwellings Electrical and DHW Load Profiles Generators Development for $\mu$ CHP Systems Using RES Coupled to Buildings Applications." Paper presented at the 6th International Building Physics Conference (IBPC 2015), Energy Procedia 78 (2015) 1919-1924. doi:10.1016/j.egypro. 2015.11.372.

Burhenne, S., D. Wystrcil, M. Elci, and S. Narmsara. 2013. "Building Performance Simulation Using Modelica: Analysis of the Current State and Application Areas." Proceedings of BS2013: 13th Conference of International Building Performance Simulation Association, Chambéry, France, August 26-28.

Carmo, C., O. Dumont, B. Elmegaard, and Detlefsen Nielsen. 2015. "Experimental Validation of a Domestic Stratified Hot Water Tank Model in Modelica for Annual Performance Assessment." ORC 2015 Conference, Brussels, Belgium.

CEN. 2008. prEN12977-3. Thermal Solar Systems and Components - Custom Built Systems - Part 3: Performance Test Methods for Solar Water Heater Stores. Technical report.

Chow, T. 2003. "Performance Analysis of Photovoltaic-thermal Collector by Explicit Dynamic Model." Solar Energy 75: 143-152.

Danish Energy Agency. 2015. Accessed 22 July. https://www. retsinformation.dk/forms/r0710.aspx?id $=152758$.

Duffie, J. A., and W. A. Beckham. 2006. Solar Thermal Engineering of Thermal Processes. Wisconsin, Madison: John Wiley and Sons.

Dumont, O., C. Carmo, F. Randaxhe, S. Quoilin, and V. Lemort. 2015. "Performance Comparison of Two Types of Technologies Associated with a Positive Energy Building: A Reversible Heat Pump/ORC Unit and a Heat Pump Coupled with PV Panels." Proceedings of the ISES Solar World Congress (SWC 2015). International Solar Energy Society, Liege, Belgium, pp. 1-6.

Dumont, O., S. Quoilin, and V. Lemort. 2014. "Experimental Investigation of a Scroll Unit Used as a Compressor and as an Expander in a Reversible Heat Pump/ORC Unit." Proceedings of the refrigeration conference in Purdue.

Dumont, O., S. Quoilin, and V. Lemort. 2015. "Experimental Investigation of a Reversible Heat Pump/Organic Rankine Cycle Unit Designed to be Coupled with a Passive House (Net Zero Energy Building)." International Journal of Refrigeration 54: 190-203. http://dx.doi.org/10.1016/ j.ijrefrig.2015.03.008.

Dupeyrat, P., P. Ménézo, and S. Fortuin. 2014. "Study of the Thermal and Electrical Performances of PVT Solar Hot Water System." Energy and Buildings 68: 751-755.

Energinet. 2015. Accessed 2 January. http://energinet.dk/DA/El/ Solceller/Har-du-solceller/Sider/Pristillaeg.aspx.

EnergyPlus. 2015. http://apps1.eere.energy.gov/buildings/energy plus/weatherdata_about.cfm.

European Commission. 2012. Energy Markets in the European Union in 2011. doi:10.2833/12806.

European Commission. 2013. Progress by Member States towards Nearly Zero-Energy Buildings, COM (2013) 483.

EV-power. 2014. Accessed 29 October. http://www.ev-power.eu/ Winston-300Ah-1000Ah/.

Fischer, S., W. Heidemann, H. Müller-Steinhagen, B. Perers, P. Bergquist, and B. Hellströmd. 2004. "Collector Test Method under Quasi-dynamic Conditions According to the European Standard EN 12975-2.” Solar Energy 76: 117-123.

Freeman, J., K. Hellgardt, and C. Markides. 2015. "An Assessment of Solar-Powered Organic Rankine Cycle Systems for 
Combined Heating and Power in UK Domestic Applications." Applied Energy 138: 605-620.

Georges, E., S. Gendebien, S. Bertagnolio, and V. Lemort. 2013. "Impact of the Integration of Various Heating Technologies on the Energy Load Profiles of the Belgian Residential Building Stock." Proceedings of the 8th renewable energy storage conference and exhibition (IRES 2013).

He, W., Tin-Tai Chow, Jie Ji, Jianping Lu, G. Pei, and Lokshun Chan. 2006. "Hybrid Photovoltaic and Thermal SolarCollector Designed for Natural Circulation of Water." Applied Energy 83: 199-210.

Herrando, M., C. Markides, and K. Hellgardt. 2014. "A UKBased Assessment of Hybrid PV and Solar-Thermal Systems for Domestic Heating and Power: System Performance." Applied Energy 122: 288-309.

Innogie ApS. 2013. "Thermal Solar Absorber System Generating Heat and Electricity." US Patent, 2013/025778 A1, https://patentscope.wipo.int/search/en/detail.jsf?docId = WO2012041323\&recNum $=27 \&$ docAn $=$ DK2011050363 \&queryString $=(\mathrm{FP} /$ solar $\% 20 \mathrm{AND} \% 20 \mathrm{FP} /$ thermal $\% 20$ AND $\% 20 \mathrm{FP} /$ electricity) $\% 20 \& \max R e c=107$.

Klein, S. A. 1975. "Calculation of Flat-Plate Loss Coefficient." Solar Energy 17: 79. http://adsabs.harvard.edu/abs/1975 SoEn ... 17 ...79K.

Knight, I., J. Adnot, J.-L. Alexandre, P. Andre, M.-N. Assimakopoulos, V. Butala, R. Hitchin, M. Masoero, C. Spitzbart, and D. Wright. 2010. "HARMONAC - Harmonizing Air Conditioning Inspection and Audit, Procedures in the Tertiary Building Sector, Energy Consumption in European Air Conditioning Systems and the Air." https://ec.europa.eu/energy/intelligent/projects/en/projects /harmonac.

Marszal, A. J., P. Heiselberg, J. S. Bourrelle, E. Musall, K. Voss, I. Sartori, and A. Napolitano. 2011. "Zero Energy Building - A Review of Definitions and Calculation Methodologies." Energy and Buildings 43 (4): 971-979.

Masy, G. 2007. "Definition and Validation of a Simplified Multizone Dynamic Building Model Connected to Heating System and HVAC Unit." PhD thesis, University of Liege, Liege, Belgium.

Masy, G., E. Georges, C. Verhelst, V. Lemort, and P. André. 2015. "Smart Grid Energy Flexible Buildings through the use of Heat Pumps and Building Thermal Mass as Energy Storage in the Belgian context." Science and Technology for the Built Environment - Ashrae 21 (6): 8000-811. doi:10.1080/23744731.2015.1035590.

Muller, D., and A. H. Badakhshani. 2010. "Gebaude und Anlagensimulati Mit Modelica.” Proceedings of BauSIM 2010. http://info.tuwien.ac.at/bausim/conftool/mueller-2010-geko ppelte_gebaeude-_und_anlagensimulation_mit_modelica198.pdf.

Nytsch-Geusen, M., and S. Unger. 2009. "Modelling of Complex Thermal Energy Supply Systems Based on the
Modelica-Library Fluidflow.” Proceedings of the 6th International Modelica Conference. http://webcache.googleuser content.com/search?q = cache:D2BJ4wVYr8IJ:citeseerx.ist psu.edu/viewdoc/summary3FDOI3D10.1.1.472.1996 + \&cd $=3 \& \mathrm{hl}=\mathrm{fr} \& \mathrm{ct}=\mathrm{clnk} \& \mathrm{gl}=$ be.

Perers, B. 1997. "An Improved Dynamic Solar Collector Test Method for Determination of Non-Linear Optical and Thermal Characteristics with Multiple Regression." Solar Energy 59: 163-178.

PICIR (Potsdam Institute for Climate Impact Research). 2015. Accessed 30 July. www.pik-potsdam.de.

Quoilin, S., A. Desideri, J. Wronski, and I. Bell. 2014. "ThermoCycle: A Modelica Library for the Simulation of Thermodynamic Systems.” Proceedings of the 10th International Modelica Conference 2014, Lund, Sweden.

Quoilin, S., O. Dumont, K. Harley, and V. Lemort. 2015. "Design, Modeling and Performance Optimization of a Reversible Heat Pump/Organic Rankine Cycle System for Domestic Application." Journal of Engineering for Gas Turbines and Power 138: 011701. doi:10.1115/1.4031004.

Quoilin, S., O. Dumont, and V. Lemort. 2013. "Design, Modelling and Performance Optimization of a Reversible HP/ORC Prototype." Proceedings of the ORC 2013 Conference, Rotterdam, Netherlands.

Schimpf, S., K. Uitz, and R. Span. 2011. "Simulation of a Solar Assisted Combined Heat Pump-Organic Rankine Cycle System." Proceedings of World Renewable Energy Congress, Sweden.

Schnieders, J. 1997. "Comparison of the Energy Yield Predictions of Stationary and Dynamic Solar Collector Models and the Models' Accuracy in the Description of a Vacuum Tube Collector." Solar Energy 61: 179-190.

TESS. 2006. "Standard Component Library Overview." http:// web.mit.edu/parmstr/Public/Documentation/03-Component LibraryOverview.pdf.

Trnsys. 2015. "Tess Component Libraries." Accessed 1 September. http://www.trnsys.com/tess-libraries/TESSLibs17_ General_Descriptions.pdf.

Wang, P. G., M. Scharling, K. P. Nielsen, and C. Kern-Hansen. 2010. “Technical Report 13-19: 2001 - 2010 Danish Design Reference Year, Climate Dataset for Technical Dimensioning in Building, Construction and other Sectors." Accessed 1 September 2015. http://www.dmi.dk/fileadmin/Rapporter/ TR/tr13-19.pdf.

Wetter, M., W. Zuo, and T. S. Nouidui. 2011. "Recent Developments of the Modelica 'Buildings'. Library for Building Energy and Control Systems." Proceedings of the 8th International Modelica Conference, Dresden, Germany.

Wetter, M., W. Zou, T. S. Nouidui, and X. Pang. 2013. "Modelica Buildings Library." Journal of Building Performance Simulation, March 2013, doi:10.1080/19401493.2013. 765506 


\section{Appendix}

Figure A1 presents the T-s diagram for the HP mode (dashed lines are the theoretical cycle, plain lines are the experiment). The different steps of the process are observed: expansion valve exhaust and evaporator supply (1), evaporator exhaust and four-way valve (low pressure) supply (2), four-way valve exhaust and compressor supply (3), compressor exhaust and four-way valve (high pressure) supply (4), four-way valve exhaust and condenser supply (5), condenser exhaust and sub-cooler supply (6), sub-cooler exhaust and expansion valve supply (7). (Dumont, Quoilin, and Lemort 2015). More details are provided in Dumont, Quoilin, and Lemort (2015).

Figure A2 depicts the T-s diagram for the ORC mode (comparison between experiments and theory). The different steps of the process are observed: Sub-cooler exhaust and pump supply (1), pump exhaust and evaporator supply (2), evaporator exhaust and four-way valve supply (high pressure) (3), four-way valve exhaust and expander supply (4), expander exhaust and four-way valve (low pressure) supply (5), four-way exhaust and condenser supply (6) and, condenser exhaust and sub-cooler supply (7). (Dumont, Quoilin, and Lemort 2015). More details are provided in Dumont, Quoilin, and Lemort (2015).

Figure A3 shows the hydraulic scheme of the thermal heat storage. Unit loop (supply and return) is the reversible HP/ORC unit (direct heating or heat pump). In heat pump mode, it is connected to the condenser and in direct heating mode is connected to the solar roof. FH is the floor heating loop while DHW is the Domestic Hot water loop.

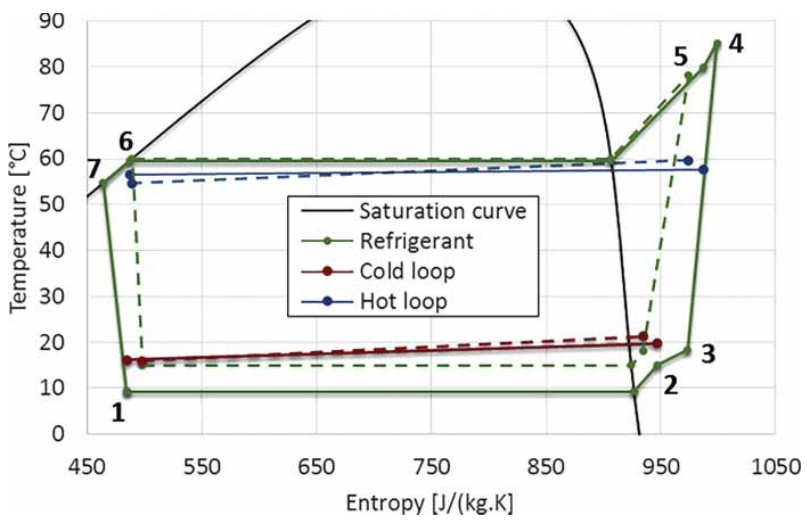

Figure A1. T-s diagram for the HP mode (dashed lines are the theoretical cycle, plain lines are the experiment).

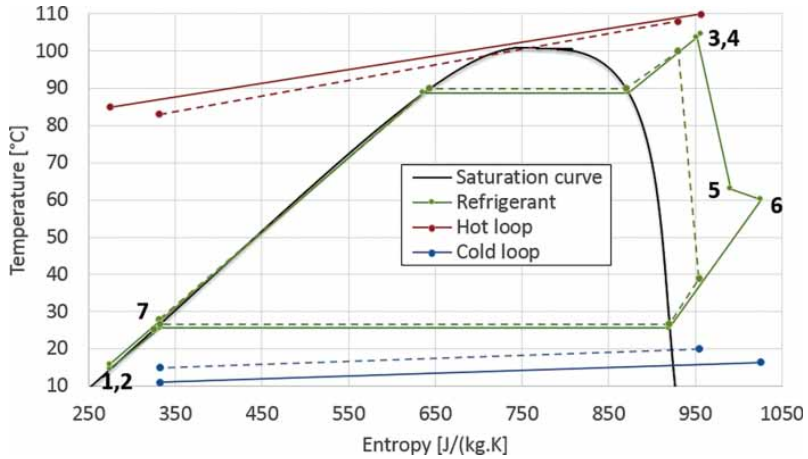

Figure A2. T-s diagram for the ORC mode (comparison between experiments and theory). Dashed lines are the theory, plain line is the experiment.

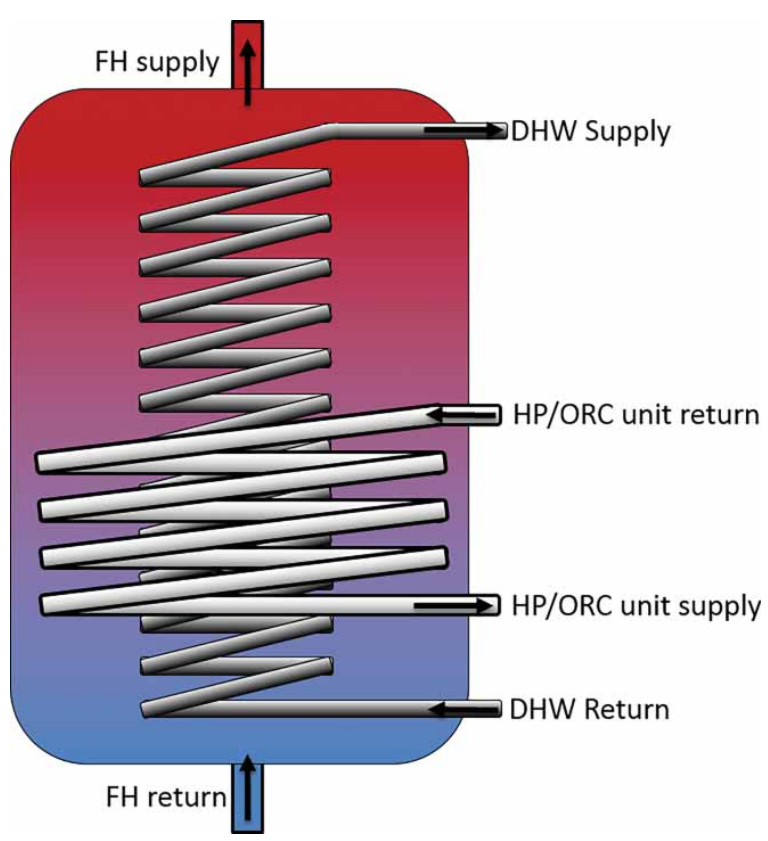

Figure A3. Hydraulic scheme of the thermal heat storage. Unit loop (supply and return) is the reversible HP/ORC unit (direct heating or heat pump). In heat pump mode, it is connected to the condenser and in direct heating mode is connected to the solar roof. FH is the floor heating loop while DHW is the domestic hot water loop. 


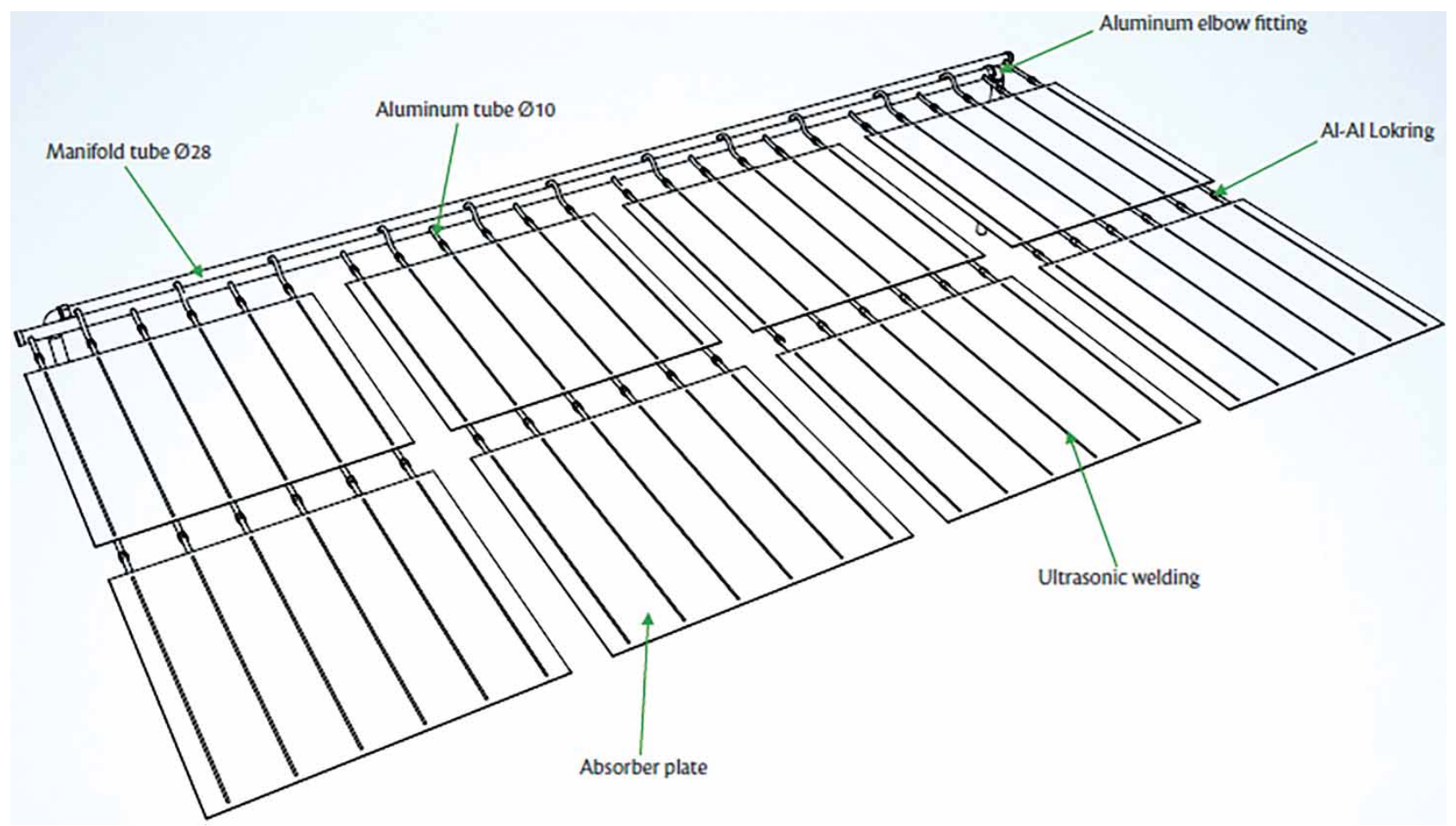

Figure A4. Patented solar roof collector scheme.

Table A1. Meaning and value of the terms of Equation (3).

\begin{tabular}{lll}
\hline Term & \multicolumn{1}{c}{ Name } & \multicolumn{1}{c}{ Value/expression } \\
\hline$\beta$ & Collector tilt & $5\left({ }^{\circ} \mathrm{C}\right)$ \\
$\mathrm{v}$ & Empirical constant & $520\left(1-0.000051 \beta^{2}\right)$ \\
$\mathrm{e}$ & Empirical variable & $0.43\left(1-\frac{100}{T_{m}}\right)$ \\
& & 0.88 \\
$\varepsilon_{g}$ & Emittance of glass & 0.95 \\
$\varepsilon_{p}$ & Emittance of plate & $\left(1+0.089 \cdot h_{w}-\right.$ \\
$\mathrm{n}$ & Empirical constant & $\left.0.1166 h_{w} \varepsilon_{p}\right)(1+$ \\
& & $0.07866 N)$ \\
& & $2\left(\mathrm{~W} \mathrm{~m}^{-2} \mathrm{~K}^{-1}\right)$ \\
$h_{w}$ & Wind heat transfer & 0.00591 \\
$\mathrm{~s}$ & coefficient & 0.133 \\
$\mathrm{z}$ & Empirical constant & \\
\hline
\end{tabular}

Figure A4 presents the patented solar roof collector scheme. This roof acts is an integrated solution replacing a classical roof. The pipes are composed of aluminium.

Figure A5 presents the layout of the GHX. The right-hand loop is a cooling system and the bottom loops are the GHX with two main hoses of connection. 
Table A2. Five zones of the house characteristics. For each zone, the floor area, the total volume, the heat exchange coefficient ( $U$-value) for the roof, the slab, the wall and the window are given. The area of windows and walls, the infiltration rate, the nominal lighting and appliances power and the air-temperature set-points are also provided.

\begin{tabular}{|c|c|c|c|c|c|c|}
\hline & Unit & Zone 1 & Zone 2 & Zone 3 & Zone 4 & Zone 5 \\
\hline Floor area & $\mathrm{m}^{2}$ & 41.8 & 18.2 & 7.8 & 19.1 & 45.7 \\
\hline Volume & $\mathrm{m}^{3}$ & 117.2 & 45.5 & 19.5 & 47.8 & 114.3 \\
\hline Slab $U$-Value & $\mathrm{W} / \mathrm{m}^{2} \mathrm{~K}$ & 0.08 & 0.08 & 0.08 & 0.08 & 0.08 \\
\hline Roof $U$-Value & $\mathrm{W} / \mathrm{m}^{2} \cdot \mathrm{K}$ & 0.09 & 0.09 & 0.09 & 0.09 & 0.09 \\
\hline External wall area & $\mathrm{m}^{2}$ & none & 20.4 & 4.5 & 24.8 & 41.5 \\
\hline External wall $U$-value & $\mathrm{W} / \mathrm{m}^{2} \cdot \mathrm{K}$ & none & 0.15 & 0.15 & 0.15 & 0.15 \\
\hline Window area (orientation) & $\mathrm{m}^{2}$ & $14.7(\mathrm{~S})$ & $2.4(\mathrm{~S})$ & $0.84(\mathrm{~W})$ & $\begin{array}{l}0.84(\mathrm{~W}) \\
0.84(\mathrm{~N})\end{array}$ & $\begin{array}{l}6.7(\mathrm{E}) \\
2.4(\mathrm{~S})\end{array}$ \\
\hline Window $U$-value & $\mathrm{W} / \mathrm{m}^{2} \mathrm{~K}$ & 0.63 & 0.68 & 0.8 & 0.8 & 0.8 \\
\hline Window solar factor & - & 0.5 & 0.5 & 0.5 & 0.5 & 0.5 \\
\hline Infiltration rate & $\mathrm{ACH}$ & $\begin{array}{c}0.3 \\
\text { Kitchen }\end{array}$ & 0.3 & 0.3 & 0.3 & 0.3 \\
\hline Space activity & - & Dining & Main Bedroom & Bathroom & Hall Others & Living Bedroom \\
\hline Lighting nominal power & $\mathrm{W} / \mathrm{m}^{2}$ & 5 & 5 & 3 & 3 & 5 \\
\hline Appliances nominal power & $\mathrm{W} / \mathrm{m}^{2}$ & 3 & $\begin{array}{l}3 \\
\text { Only }\end{array}$ & $\stackrel{3}{\text { Only }}$ & $\stackrel{3}{\text { Only }}$ & $\begin{array}{c}3 \\
\text { Only }\end{array}$ \\
\hline Air-temperature Set-point & ${ }^{\circ} \mathrm{C}$ & 20 & $\begin{array}{l}\text { Imposed in } \\
\text { zone } 1\end{array}$ & $\begin{array}{l}\text { imposed in } \\
\text { zone } 1\end{array}$ & $\begin{array}{l}\text { imposed in } \\
\text { zone } 1\end{array}$ & $\begin{array}{l}\text { Imposed in } \\
\text { zone } 1\end{array}$ \\
\hline
\end{tabular}

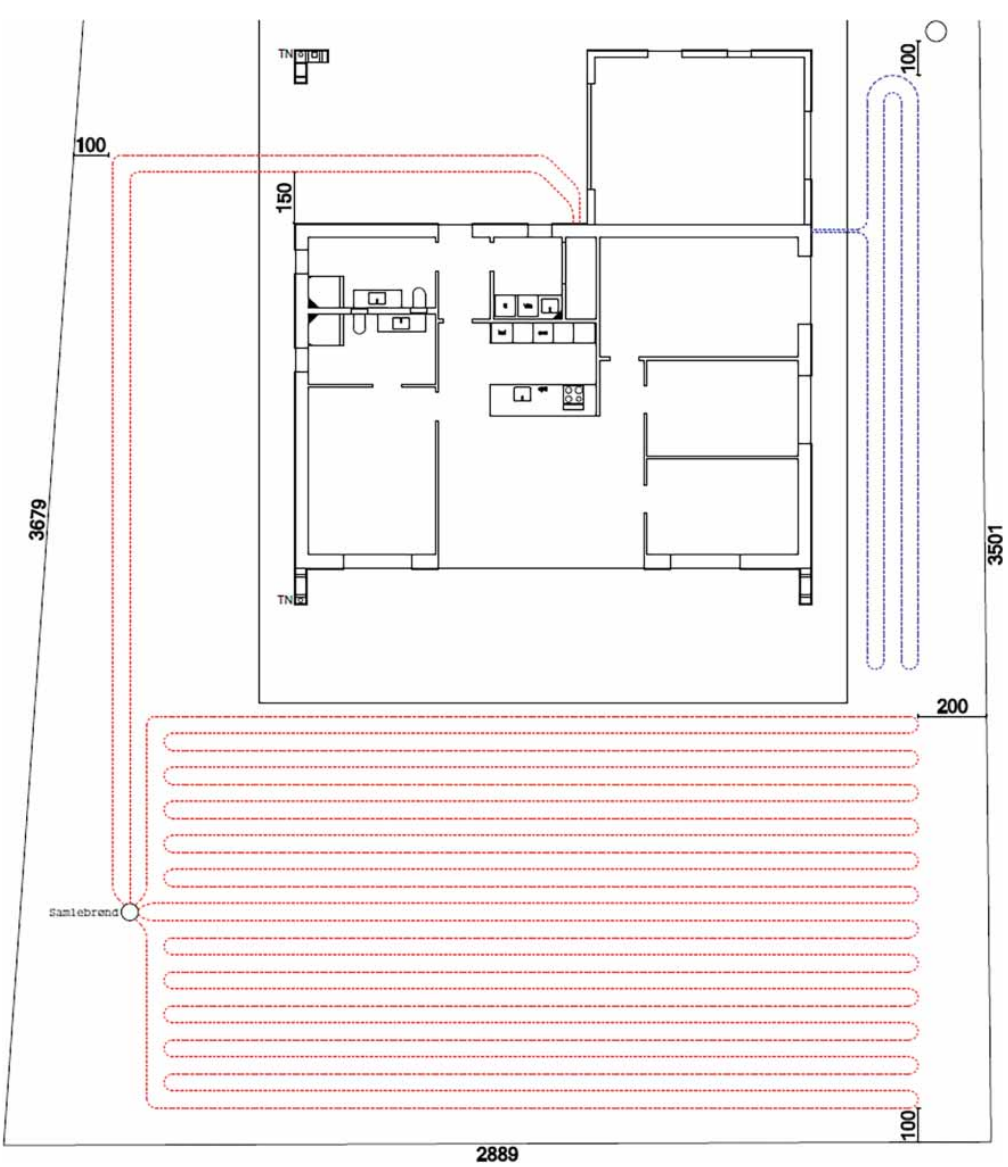

Figure A5. Layout of the GHX. The right-hand loop is a cooling system and the bottom loops are the GHX with two main hoses of connection. 
Table A3. Parameters of the reduced-order model calibrated based on the finite-element model response. The heat exchange between the pipes and the central soil is modelled with three resistances in series (soil, tube and convective). The thermal behaviours of the surface and sub-soil are modelled through a thermal capacity and a thermal resistance. An additional convective resistance is added to the surface layer to take into account the exchange with the air. The related thicknesses allow to evaluate the mass of each layer. The inertia of the central soil is characterized by an equivalent thermal capacity.

\begin{tabular}{llcc}
\hline & \multicolumn{1}{c}{ Parameter } & Value & Unit \\
\hline \multirow{2}{*}{ Surface } & Thermal capacity & $3 \mathrm{E} 07$ & $\mathrm{~J} / \mathrm{K}$ \\
& Related thickness & 0.033 & $\mathrm{~m}$ \\
& Thermal resistance & 0.0011 & $\mathrm{~K} / \mathrm{W}$ \\
& Convective resistance & $1.58 \mathrm{E}-04$ & $\mathrm{~K} / \mathrm{W}$ \\
Sub-soil & Thermal capacity & $4 \mathrm{E} 09$ & $\mathrm{~J} / \mathrm{K}$ \\
& Related thickness & 4.47 & $\mathrm{~m}$ \\
& Thermal resistance & 0.005 & $\mathrm{~K} / \mathrm{W}$ \\
Central soil & Thermal capacity & $1.2 \mathrm{E} 09$ & $\mathrm{~J} / \mathrm{K}$ \\
& Related thickness & 2.01 & $\mathrm{~m}$ \\
Pipes & Convective resistance & $1.26 \mathrm{E}-04$ & $\mathrm{~K} / \mathrm{W}$ \\
& Tube resistance & $4.89 \mathrm{E}-05$ & $\mathrm{~K} / \mathrm{W}$ \\
& Soil resistance & $2 \mathrm{E}-04$ & $\mathrm{~K} / \mathrm{W}$ \\
Contract & Area & 299 & $\mathrm{~m}{ }^{2}$ \\
surface & & & \\
\hline
\end{tabular}

Table A4. Envelope characteristics of different typical buildings. Each building is characterized by different coefficients of heat transmission for the roof, the floor slab, the external wall and the window and an infiltration rate coefficient.

\begin{tabular}{|c|c|c|c|}
\hline $\begin{array}{l}\text { Coefficient of heat } \\
\text { transmission }\end{array}$ & Danish & K15 & $\mathrm{K} 30$ \\
\hline $\operatorname{Roof}\left(\mathrm{W} \mathrm{m}^{-2} \mathrm{~K}^{-1}\right)$ & 0.09 & 0.093 & 0.228 \\
\hline Floor slab $\left(\mathrm{W} \mathrm{m}^{-2} \mathrm{~K}^{-1}\right)$ & 0.08 & 0.123 & 0.258 \\
\hline $\begin{array}{l}\text { External wall } \\
\qquad\left(\mathrm{W} \mathrm{m}^{-2} \mathrm{~K}^{-1}\right)\end{array}$ & 0.15 & 0.102 & 0.245 \\
\hline Window $\left(\mathrm{W} \mathrm{m}^{-2} \mathrm{~K}^{-1}\right)$ & 0.63 & 0.9 & 1.2 \\
\hline $\begin{array}{l}\text { Infiltration rate }(50 \mathrm{~Pa}) \\
\quad\left(\mathrm{m}^{3} \mathrm{~h}^{-1} \mathrm{~m}^{-2}\right)\end{array}$ & 2.51 & 0.6 & 0.35 \\
\hline
\end{tabular}

